\title{
Comparison of the effectiveness of manual cleaning, hydrogen peroxide vapour and ultraviolet-c in disinfection of hospital equipment
}

\author{
Usporedba učinkovitosti ručnog čišćenja, pare vodikovog peroksida i \\ ultraljubičastog C zračenja u dezinfekciji bolničke opreme \\ Yosra Sedaghat' ${ }^{1}$ Seifollah Gholampour', Farhad Tabatabai Ghomshe² \\ ${ }^{1}$ Department of Biomedical Engineering, North Tehran Branch, Islamic Azad University, P.O.B. 1651153311, Tehran, Iran. \\ ${ }^{2}$ Ergonomics Department, University of Social Welfare and Rehabilitation Sciences (USWR), P.0.B. 2435587634, Tehran, Iran.
}

Keywords:
ultraviolet-c
disinfection
hydrogen peroxide vapour
manual cleaning
hospital equipment
Ključne riječi:
ultraljubičasto-C zračenje
dezinfekcija
para vodikovog peroksida
ručno čiš́enje
bolnička oprema

Primljeno: 17.8.2019.

Received: 17.8.2019.

Prihvaćeno: 22.9.2019

Accepted: 22.9.2019.

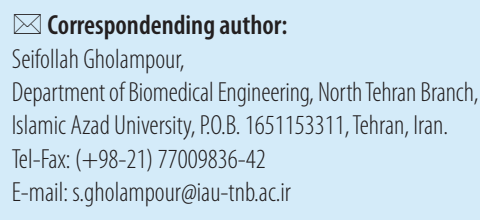

\begin{abstract}
Hospitals are the focus of many infections which cause the intensification of the patients' illness and even their death. The number of bacteria on various hospital equipment was counted before and after being disinfected with manual cleaning (MC), hydrogen peroxide vapour (HPV) and ultraviolet-C (UV-C). The effectiveness of disinfection of hospital beds in intensive care unit (ICU) using the three methods MC, HPV and UV-C has been 66.67\%, $100 \%$ and 50\%, respectively. Hence, the effectiveness of HPV method in the disinfection of this unit has been higher than others. The effectiveness of otoscope disinfection in the ICU and blood pressure meter in the operating room with three methods of MC, HPV and UV-C has been $0 \%, 50 \%$ and $100 \%$, respectively. So, for disinfecting these small outfits, UV-C method has proven to be the best one. In case of programming, the correct move of portable UV-Cs for complete coverage of massive equipment, disinfection with UV-C method may be considered more effective than other methods.
\end{abstract}

\section{Sažetak}

Bolničke sredine izvorište su mnogih infekcija koje mogu uzrokovati pogoršanje bolesti kod pacijenata, pa čak i njihovu smrt. Broj bakterija na različitoj medicinskoj opremi analizirao se prije i nakon dezinfekcije, odnosno ručnog čišćenja, korištenja pare vodikovog peroksida i ultraljubičastog-C svjetla (UV-C). Učinkovitost dezinfekcije bolničkih kreveta u jedinicama intenzivnog liječenja, koristeći ove tri metode, iznosila je 66,67\% za ručno čišcenje, 100\% za upotrebu pare vodikova peroksida te 50\% za UV-C zračenje. Dakle, učinkovitost pare vodikovog peroksida u dezinfekciji bolničkih kreveta bila je veća u usporedbi s ostalim metodama. Učinkovitost dezinfekcije otoskopa u jedinicama intenzivnog liječenja i tlakomjera u operacijskim dvoranama, korištenjem ove tri metode, iznosila je 0\% za ručno čišcenje, 50\% za upotrebu pare vodikovog peroksida te 100\% za UV-C zračenje. Dakle, ultraljubičasto C zračenje pokazalo se najučinkovitijom metodom za dezinfekciju manje opreme. Ova metoda dezinfekcije, u slučaju mogućnosti programiranja te ispravnog prijenosa uređaja za dezinfekciju UV-C zračenjem, radi potpune pokrivenosti veće opreme, može se smatrati učinkovitijom od ostalih metoda.

\section{Introduction}

Attention to hospital infections dates back to the years of formation of preliminaries of microbiology science in the early $1840 \mathrm{~s}^{[1]}$. Hospitals, as a place for the patients' treatment, reasonably shouldn't be a factor for the creation of diseases, but in many cases, hospitals are the origin of many infections, too. Various pathogenic factors such as bacteria, viruses and fungi may be the source of hospital infections. Hospitalized patients, based on individual conditions, especially nature of their disease, sometimes suffer from weakness of the immune system which causes their high liability for being affected by infectious diseases. In such conditions, pathogenic factors, especially opportunistic factors are transferred to the hospitalized patient and cause infections in the patient ${ }^{[2]}$. Besides patients who have a weak immune system, these infections may interrupt the process of treatment in patients suffering from diseases of areas of neuroscience ${ }^{[3-9]}$, orthopae$\operatorname{dics}^{[10,11]}$, and cardiovascular diseases ${ }^{[12-15]}$. Ways of transfer of microorganisms in the hospital include contact with contaminated surface, air and vectors such as mosquitos and flies ${ }^{[16]}$. So, regular disinfection of the patient's environment is necessary for the reduction 
of the risk of hospital infections. Common methods of disinfection include manual cleaning (MC), hydrogen peroxide vapour (HPV) and ultraviolet-C (UV-C) ${ }^{[17]}$. Therefore, this study focused on comparing the effectiveness of these three methods. In MC method, the hospital nurse provides aid and sanitary workers clean the surfaces using disinfecting solutions. In UV-C method, the UV radiation is used on the surfaces to remove microorganisms and in the third method, a device is used that scatters HPV in the space causing surface disinfection.

Several studies have been performed on disinfection of the hospital surfaces and spaces. Kovach et al. were exploring the possibilities of a robot that disinfects the hospital surfaces with xenon light. Using this robot for radiation of xenon light has proved a minimum $2.4 \%$ more effective than using MC method ${ }^{[18]}$. Gostine et al. investigated the effectiveness of UV-C in the reduction of contamination of keyboard of computers existing in the intensive care unit (ICU). The results of this study showed that reduction of the time of exposing keyboards to UV-C ray from 10 to 6 minutes, leads to only a $0.4 \%$ increase in the effectiveness of this method $^{[19]}$. Ghannoum et al. evaluated shoe disinfection in the hospital space using UV-C method ${ }^{[20]}$. The results showed that by increasing each 45 -minute period in UV-C radiation, the effectiveness of this method increased to $6.3 \%{ }^{[20]}$. Timmermann et al. investigated the disinfection of drinking water in hospitals using UV-C method ${ }^{[21]}$. The results indicated high effectiveness of UV-C method on bacteria existing in the water. One among various bacteria studied in this research was Escherichia coli. Messina et al. conducted a study on a new device consisting of UV-C radiation by an LED lamp for automatic disinfection of stethoscope ${ }^{[22]}$. The results of this study showed that in one minute, 94.3\% of Escherichia coli bacteria were infected in the whole stethoscope except around the periphery of the stethoscope membranes ${ }^{[22]}$. Consequently, several studies were conducted on utilizing modern technologies in the improvement of the disinfection of environmental surfaces and hospital rooms ${ }^{[23,24]}$.

The main objective of the present study was to compare the effectiveness of three common methods of hospital disinfection including MC, HPV and UV-C with a variety in type and number of equipment for disinfecting three bacteria -Escherichia coli, Staphylococcus aureus and Pseudomonas aeruginosa.

\section{Methods}

Tests were performed for 8 weeks on the equipment in the ICU, emergency room and operating room. Equipment in the ICU included hospital bed, infu- sion pump, suction device, ventilator, otoscope, blood pressure meter, bed mattress, defibrillator and stethoscope and operating room equipment included electrosurgery device, infusion pump, stethoscope, blood pressure meter, surgical bed, surgical lighting, anaesthesia device and defibrillator device and emergency room equipment included stethoscope, otoscope and blood pressure meter. The selected equipment after the patient's discharge (without considering the type of illness of the individual) was exposed to microbial culture and then the number of bacteria was counted. Then, all this equipment was separately disinfected with all three methods of MC, HPV and UV-C and again exposed to microbial culture and bacteria counting. It should be mentioned that the bacteria investigated in this study included Escherichia coli, Staphylococcus aureus and Pseudomonas aeruginosa, as being the most common and riskier pathogens in hospital infections ${ }^{[25-28]}$.

\section{Disinfection with manual cleaning}

In this study, cleanliness, washing pickling smut and disinfection for all equipment from top to bottom and from clean to dirty part was performed as follows: - hospital bed: after patient discharge, the beds were sprayed with intermediate-level alcohol spray, washed with detergent and then dried. It should be mentioned that $5 \%$ bleach was used for infectious patients;

- devices such as infusion pump, suction device, otoscope, defibrillator, electrosurgery device, ventilator, surgical lighting and anaesthesia device were sprayed with a napkin and intermediate-level disinfection solution spray;

- blood pressure meter was washed in 7-day periods with bleach;

- bed mattress: after the discharge of each patient, bed mattress was disinfected with a napkin soaked in 5\% disinfecting solution (fast-acting alcohol or bleach spray) and dried. It should be mentioned that the mattress cover was waterproof.

- stethoscope: after every patient, the stethoscope was cleaned with $80 \%$ alcohol.

It should be mentioned that in the case of observation of a great amount of blood after washing, the following method was performed:- a disposable napkin was placed on contaminated surface, to completely cover the area

- a 1:10 bleach solution was poured and left for 10 minutes

- with great caution, the napkin was collected and placed in a special garbage bag 
- the area was washed with water and detergent

- the contaminated surface was again disinfected with 1:10 bleach solution.

\section{Disinfection with HPV}

For disinfection with HPV method, the Nocospray device model $1000 \mathrm{w}$ was used which turns hydrogen peroxide $\left(\mathrm{H}_{2} \mathrm{O}_{2}\right)$ to $\mathrm{OH}$-ions with hydrogen peroxide vapour technology (fogging). In this method, the device was located in the middle of the room with all doors of the drawers in the room opened, and when the operator exited the room and the room door was closed. After 15 seconds, the device was turned on and after 15 minutes of work, the device was turned off and after 30 minutes the operator entered the room and the test was performed (Nocospray, EquipMed, OXYPHARM, France).

\section{Disinfection with UV-C}

Two models of portable and wall-mounted UV-C lamps are usually used in the hospitals. Before turning on the lamp, the room ventilator should be turned off, windows and glasses covered and darkened and the doors of all dressers and cabinets in the room should be left open. It should be mentioned that before the UV-C device is turned on from outside the room, the doors sealing the room should be secured. In the portable model, since the range of radiation is defined at about $1.5 \mathrm{~m}$, for this purpose, the lamp was located in all parts of the room for 20 minutes time intervals ${ }^{[29]}$.

\section{Method design and performance testing}

In this study, the effectiveness of three methods of MC, HPV and UV-C in disinfection against three types of bacteria (Escherichia coli, Staphylococcus aureus and Pseudomonas aeruginosa) was investigated. Blood is the best environment for bacterial growth since it provides oxygen, nutrients and required heat for the growth of bacteria. Bacteria can be cultured on various environments and dishes. For example, in the cultures where its environment is fluid, culture dishes have been tubular shaped and solid environments were also cultured both in plate and tube. In this study, a solid culture environment and plate dishes were used. For performing the culture, swabs were collected from each device and placed in tightly closed capped tubes and then placed in the autoclave with a temperature of 121 for sterilization ${ }^{[30]}$. After sterilization, the device name (Figure la) was written on every tube and was taken to the culture test place along with an amount of physiological serum which was poured into the test tube. For culture, at first, the test tube cab was opened, swab was taken out and the swab cap was soaked in physiological serum. Then, it was drawn on surfaces of equipment and/or was immerged inside their pores so that, in case of bacterial presence, it would be picked up by the swab. Finally, the swab was placed in the capped tube. It should be mentioned that the stick at the end of the swab was disrupted since it was in contact with fingers. So, the culture was taken from all equipment and tubes were transferred to the microbiology laboratory.

Two culture environments of blood agar and eosin methylene blue (EMB) agar were used for the recognition of three types of bacteria Staphylococcus aureus, Escherichia coli and Pseudomonas aeruginosa and in microbiology room ${ }^{[1,25-28]}$ swabs were taken out from the tubes one by one and transferred to culture environments (Figure 1b). Culture environments were selected depending on the type of bacteria, gram-positive (Staphylococcus aureus) or gram-negative (Pseudomonas aeruginosa and Escherichia coli). Also, blood agar environment detects only gram-positive bacteria and EMB culture environment detects both gram-negative and gram-positive bacteria. Furthermore, the cap of culture environments was closed and placed in an incubator with temperature 37 for 48 hours (Figure 1c) and based on the color change of bacteria in the culture environment, type of bacteria was recognized (Figure $1 \mathrm{~d})^{[30]}$. It should be mentioned that for attenuation, a McFarland standard A0.5 was followed ${ }^{[31]}$ and colony counting was performed ${ }^{[32]}$. For preparing the McFarland standard A0.5 in the laboratory, $0.5 \mathrm{~mL}$ barium chloride $0.48 \mathrm{M}$ was mixed in $99.5 \mathrm{~mL}$ normal acid sulfuric 0.36 . The durability of this environment

Figure 1A) Steel CAPped tubes, Before Culture, B) BaCtria TRANSFER TO BLOOD AGAR CULTURE ENVIRONMENT, C) PLACEMENT OF CULTURE ENVIRONMENTS IN INCUBATOR DEVICE, D-ESCHERICHIA COLI GREW ON CULTURE ENVIRONMENT.

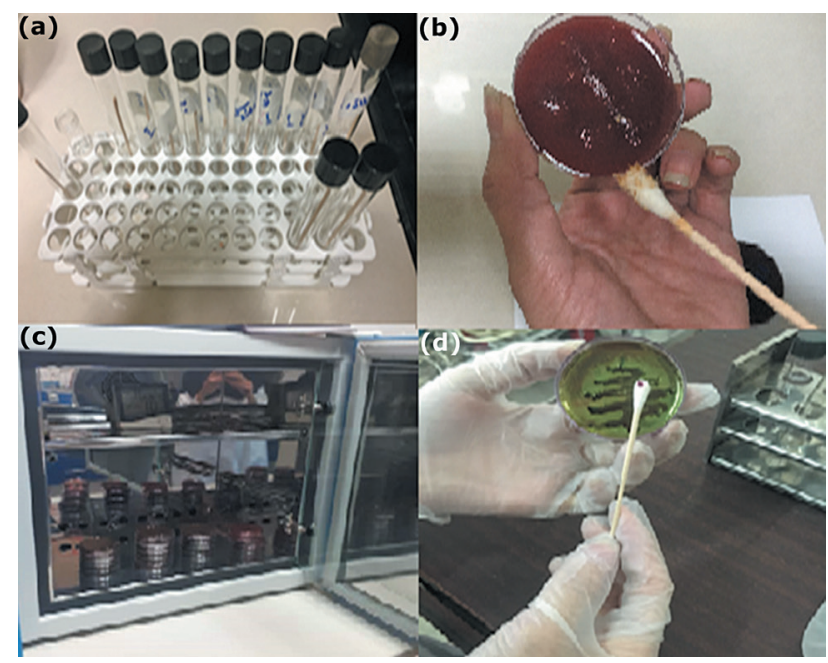


is 6 months and it was maintained in darkness and closed dishes. It should be mentioned that if sediment was observed in the tube, the solution would be considered expired ${ }^{[31]}$.

\section{Results}

The results of this section were registered and declared for eight repetitions of each test on any equipment before disinfection and also eight runs of repetition after disinfection.

\section{Effectiveness of MC Method}

The results showed that the greatest contamination with Escherichia coli has been related to hospital bed and ventilator in the ICU, infusion pump, stethoscope and surgical bed in the operating room and also blood pressure meter in the emergency room, with the affection rate of 25\% (Figure 2a and Table 1). The least contamination with Escherichia coli was related to otoscope, hospital bed, defibrillator and stethoscope in the ICU, electrosurgery device, blood pressure meter and defibrillator device in the operating room, electrosurgery device and otoscope in the emergency room with zero affection rate to their contamination (Figure 2a and Table 1). After disinfection with MC method, the highest effectiveness in disinfection of Escherichia coli has been $100 \%$ which has been related to suction device, ventilator and blood pressure meter in ICU and anaesthesia device in operating room and the least effectiveness was related to infusion pump in ICU and surgical lighting in operating room whose effectiveness has been zero (Figure 2a).

Figure $2 \mathrm{~b}$ and Table 1 showed that the greatest contamination with Staphylococcus aureus of $37.5 \%$ was related to otoscope in emergency room and the least contamination to this bacteria has been related to infusion pump, suction device, ventilator, blood pressure meter and defibrillator in ICU, infusion pump, otoscope, surgical bed, surgical lighting, anaesthesia machine and defibrillator in operating room and blood pressure meter in emergency room that the contamination rate was $0 \%$. After disinfection with MC method, the greatest effect has been related to Staphylococcus aureus $100 \%$ relating to the hospital bed in ICU and electrosurgery device in the operating room and the least effectiveness related to otoscope and bed matters in the ICU, blood pressure meter in the operating room, the effectiveness of which was $0 \%$ (Figure $2 \mathrm{~b}$ ). Figure $2 \mathrm{c}$ and Table 1 show that the greatest contamination has been to Pseudomonas aeruginosa equal to $25 \%$ which was related to suction device in the ICU and the least contamination to this bacteria was related to hospital bed, infusion pump, ventilator, otoscope, blood pressure meter, bed mattress, defibrillator and stethoscope in the ICU, electrosurgery device, stethoscope, blood pressure meter, surgical bed, surgical lighting, anaesthesia machine and defibrillator device in operating room and stethoscope, otoscope and blood pressure meter in emergency room the affection rate of which was $0 \%$. After disinfection with MC method, $100 \%$ effectiveness in the disinfection of bacteria Pseudomonas aeruginosa was related to the suction device in the ICU and infusion pump in the operating room (Figure 2c).

Figure 2A) Results SHOWn as PerCentage of CONTAMination TO ESCHERICHIA COLI BEFORE AND AFTER DISINFECTION WITH MC METHOD, B) Results SHOWN AS PERCENTAge OF CONTAMINATION WITH STAPHYLOCOCCUS AUREUS BEFORE AND AFTER DISINFECTION With MC METHOD, C) Results SHOWN AS PERCENTAGe OF CONTAMINATION WITH PSEUdOMONAS AERUGINOSA BEFORE AND AFTER DISINFECTION WITH MC METHOD.
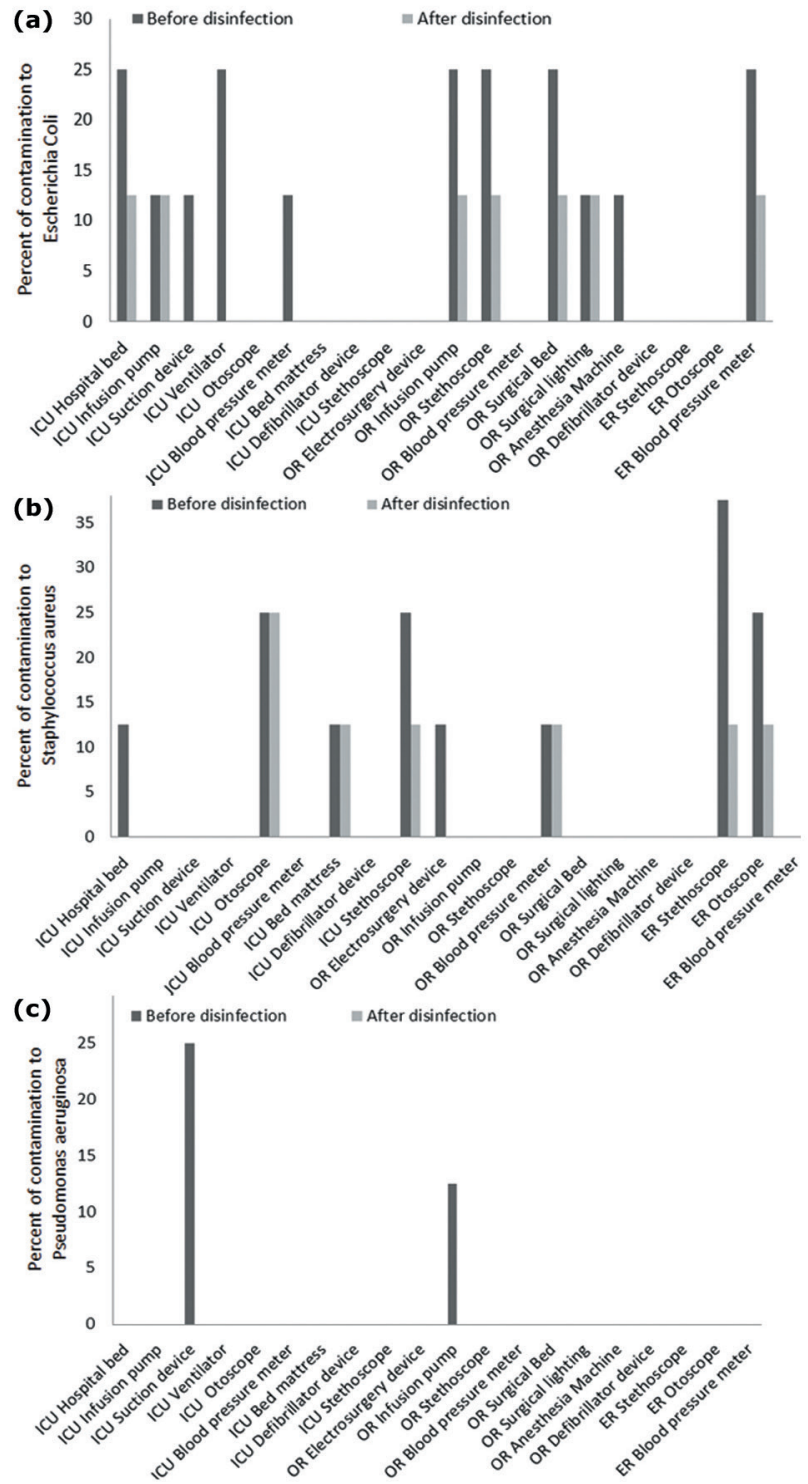


\section{Effectiveness of HPV Method}

The results presented in Figure 3a and Table 2 show that the greatest contamination with Escherichia coli was related to hospital bed, bed mattress and defibrillator in the ICU, stethoscope, blood pressure meter, surgical bed, surgical lighting, anaesthesia device in operating room and blood pressure meter in emergency room the affection rate of which was $25 \%$ and the least contamination to this bacteria has been related to infusion pump, suction device, ventilator, otoscope, blood pressure meter and stethoscope in the ICU with contamination rate of $0 \%$. After disinfection with HPV method, the greatest effectiveness in disinfection against Escherichia coli was related to hospital bed, bed mattress and defibrillator in ICU, electrosurgery device, infusion pump, surgical bed, surgical lighting, anaesthesia device and defibrillator in operating room and stethoscope and otoscope in emergency room with effectiveness rate of $100 \%$ (Figure 3a).

The greatest contamination with Staphylococcus aureus was $25 \%$ which was related to suction device and otoscope in the ICU and otoscope in the emergency room and the least contamination with this bacteria was related to hospital bed, infusion pump, blood pressure meter, bed mattress and defibrillator in the ICU, electrosurgery device, infusion pump, blood pressure meter, bed mattress and defibrillator in ICU, electrosurgery device, infusion pump, stethoscope, blood pressure meter, surgical bed, surgical lighting and defibrillator in the operating room and stethoscope and blood pressure meter in the emergency room with contamination rate of $0 \%$ (Figure $3 \mathrm{~b}$ and Table 2). After disinfection with HPV method, the greatest effectiveness against Staphylococcus aureus (100\%) was related to suction device, ventilator and stethoscope in the ICU, anaesthesia machine in the operating room and otoscope in the emergency room and the least effectiveness was related to otoscope in the ICU where, after disinfection, a $12.5 \%$ rate of contamination remained (Figure $3 b$ ).

Figure 3 and Table 2 showed that the greatest contamination with Pseudomonas aeruginosa was $12.5 \%$ which was related to infusion pump, ventilator and bed mattress in the ICU and the least contamination was related to hospital bed, suction device, otoscope, blood pressure meter, defibrillator and stethoscope in the ICU, electrosurgery device, infusion pump, stethoscope, blood pressure meter, surgical bed, surgical lighting, anaesthesia machine and defibrillator in the operating room and stethoscope, otoscope and blood pressure meter in the emergency room with contamination rate of $0 \%$. After disinfection with HPV method, effectiveness in disinfection to Pseudomonas aeruginosa has been $100 \%$ which was related to an infusion pump, ventilator and bed mattress in ICU (Figure 3c).

\section{Effectiveness of UV-C Radiation Method}

The results presented in Figure $4 \mathrm{a}$ and Table 3 show that the greatest contamination to Escherichia coli was related to hospital bed, suction device and bed mattress in ICU, electrosurgery device, surgical bed and defibrillator in operating room, with the affection rate of $25 \%$ and the least contamination to Escherichia coli was related to otoscope, defibrillator, stethoscope in ICU, infusion pump in operating room and stethoscope and otoscope in emergency room, the contamination rate of which amounted to $0 \%$. After disinfection with UV-C method, the greatest effectiveness in Escherichia coli was related to infusion pump, ventilator and blood pressure meter in ICU, electrosurgery device, stethoscope, blood pressure meter, anaesthesia machine and defibrillator device in the operating room and blood pressure meter in the emergency room that the rate of effectiveness amounted to $100 \%$ and the least effectiveness was related to surgical lighting in the operating room which was $0 \%$ (Figure 4a).

Figure 3. A) The results Showing Percentage of ContaminaTION WITH ESCHERICHIA COLI BEFORE AND AFTER DISINFECTION With HPV method, B) The Results Showing percentage of CONTAMINATION WITH STAPHYLOCOCCUS AUREUS BEFORE AND AFTER DISINFECTION WITH HPV METHOD, C) THE RESUlts SHOWING PERCENTAGE OF CONTAMINATION WITH PSEUDOMONAS AERUGINOSA BEFORE AND AFTER DISINFECTION WITH HPV METHOD.

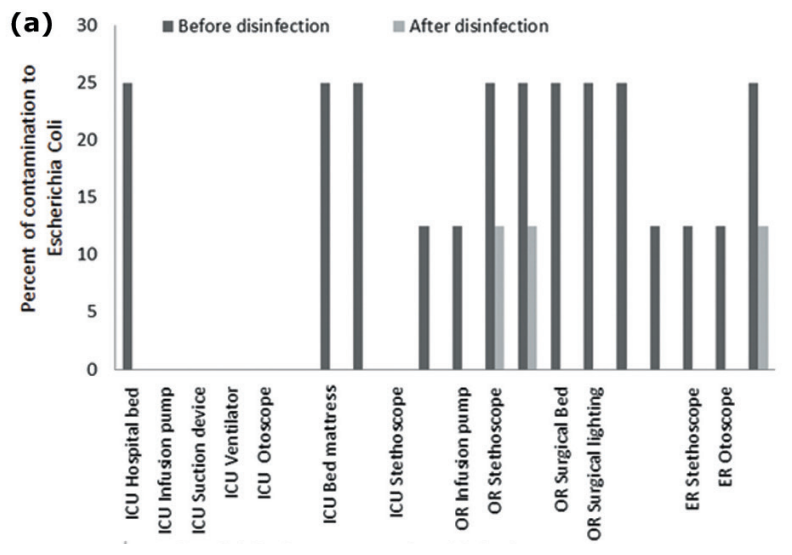



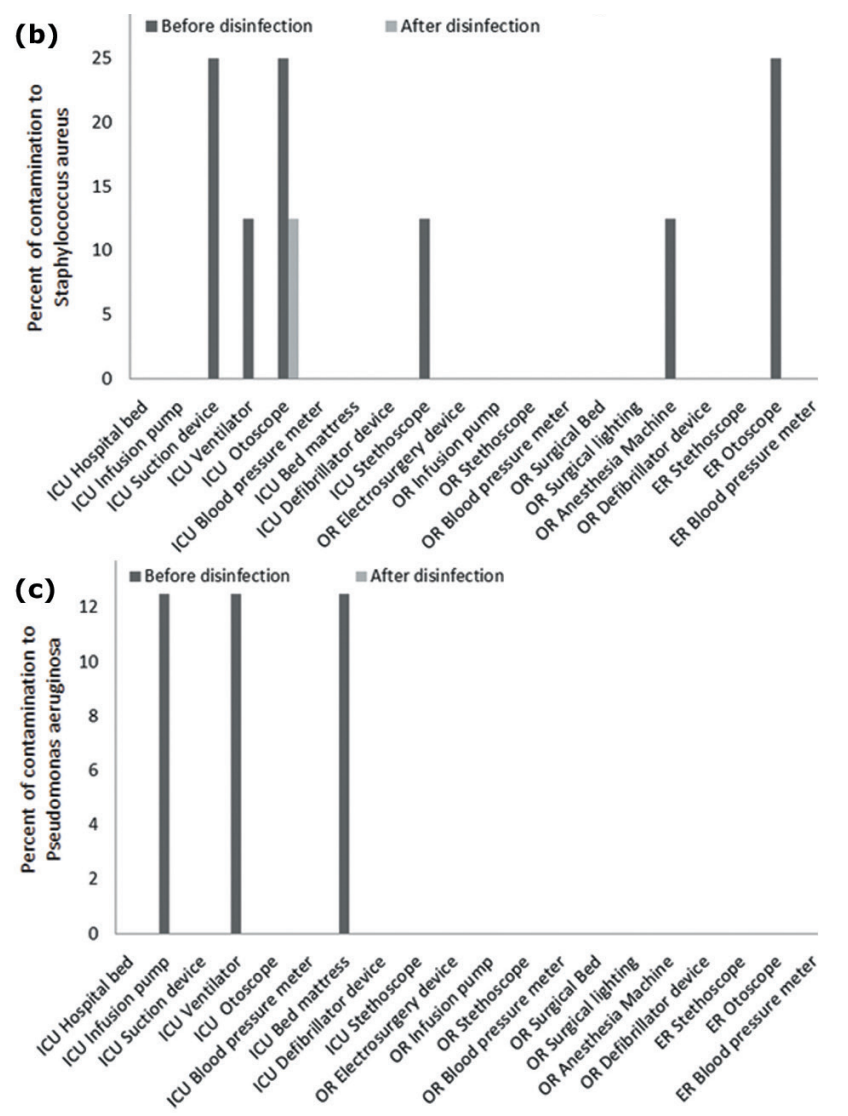

The results showed that the greatest contamination with Staphylococcus aureus of $37.5 \%$ related to otoscope in the ICU and the least contamination was related to hospital bed, infusion pump, suction device, ventilator, blood pressure meter and bed mattress in the ICU, electrosurgery device, stethoscope, blood pressure meter, surgical lighting, anaesthesia machine and defibrillator in the operating room and stethoscope and blood pressure meter in the emergency room with contamination rate of $0 \%$ (Figure 4 and Table 3). After disinfection with UV-C method, the greatest effectiveness in disinfection of Staphylococcus aureus of $100 \%$ rate was related to otoscope, defibrillator and stethoscope in the ICU, infusion pump in the operating room and otoscope in the emergency room (Figure 4a).

The results of Figure $4 \mathrm{c}$ and Table 3 show that the greatest contamination with Pseudomonas aeruginosa has been $12.5 \%$ which was related to stethoscope and otoscope in the emergency room and the least contamination was related to hospital bed, infusion pump, suction device, ventilator, otoscope, blood pressure meter, bed mattress, defibrillator and stethoscope in the ICU, electrosurgery device, infusion pump, stethoscope, blood pressure meter, anaesthesia device and defibrillator in the operating system and blood pressure meter in the emergency room with contamina- tion rate of $0 \%$. After disinfection with UV-C method, the effectiveness of this method in the disinfection of Pseudomonas aeruginosa has been $100 \%$ which has been related to surgical bed and surgical lighting in the operating room and stethoscope and otoscope in the emergency room (Figure 4c).

\section{Discussion}

In MC method, the operator cleans the contamination from the equipment with his hands, so the operator inaccuracy and imprecise disinfection and lack of consistency are possible. During the use of HPV and UV-C method, if manual cleaning hasn't been previously performed on the equipment, physical contamination after disinfection is not easily removed with this method. These facts should be taken into consideration when using these two methods. So, considering all the aforementioned aspects, the results of our tests showed that the effectiveness of disinfection on ventilator, defibrillator, suction device and blood pressure meter in the ICU and electrosurgery device, anaesthesia machine and defibrillator in the operating room using all three methods was $100 \%$. So, for disinfecting these devices, MC method which is more accessible may be easily used. According to Figure 5, the effectiveness of disinfection of hospital bed in the ICU with three methods of MC, HPV and UV-C methods has been $66.67 \%, 100 \%$ and $50 \%$, respectively and similar numbers for surgical bed in operating room have been $50 \%, 100 \%$ and $66.67 \%$, respectively and similar numbers for hospital bed in ICU, surgical lighting in operating room have been $0 \%, 100 \%$ and $50 \%$, respectively. Then, for the disinfection of these outfits, the best method is HPV method.

Effectiveness of otoscope disinfection and blood pressure meter in the operating room with three methods of MC, HPV and UV-C has been $0 \%, 50 \%$ and $100 \%$ respectively and similar numbers for stethoscope in the operating room has also been $50 \%, 50 \%$ and $100 \%$, respectively. So, for disinfecting these outfits, UV-C method is the best method for disinfection (Figure 5).

The effectiveness of disinfection of infusion pump and suction device in the ICU with three methods of MC, HPV and UV-C has been $0 \%, 100 \%$ and $100 \%$, respectively and similar numbers for stethoscope in the ICU, otoscope and blood pressure meter in emergency room have been recorded $50 \%, 100 \%$ and $100 \%$, respectively. Similar numbers were recorded for infusion pump and stethoscope in the operating room $66.67 \%$, $100 \%$ and $100 \%$, respectively. Then, for the disinfection of these devices, one of two methods of HPV and 
UV-C may be used ideally and according to existing facilities (Figure 5). Besides that for disinfection of suction device, ventilator, blood pressure meter and defibrillator in ICU and electrosurgery device, defibrillator and anaesthesia machine in operating room, MC method is an easy and accessible method but in other outfits other than bed, mattress and surgical lighting, UV-C method is the most appropriate method for disinfection and has had the greatest effectiveness.

Figure 4A) Results stated as percentage of Contamination WITH ESCHERICHIA COLI BEFORE AND AFTER DISINFECTION WITH UV-C METHOD, B) Results STATED as PERCENTAGE OF CONTAMINATION WITH STAPHYLOCOCCUS AUREUS BEFORE AND AFTER DISINFECTION WITH UV-C METHOD, C) ReSUltS STATED AS PERCENTAGE of Contamination with Pseudomonas aeruginosa before AND AFTER DISINFECTION WITH UV-C METHOD.
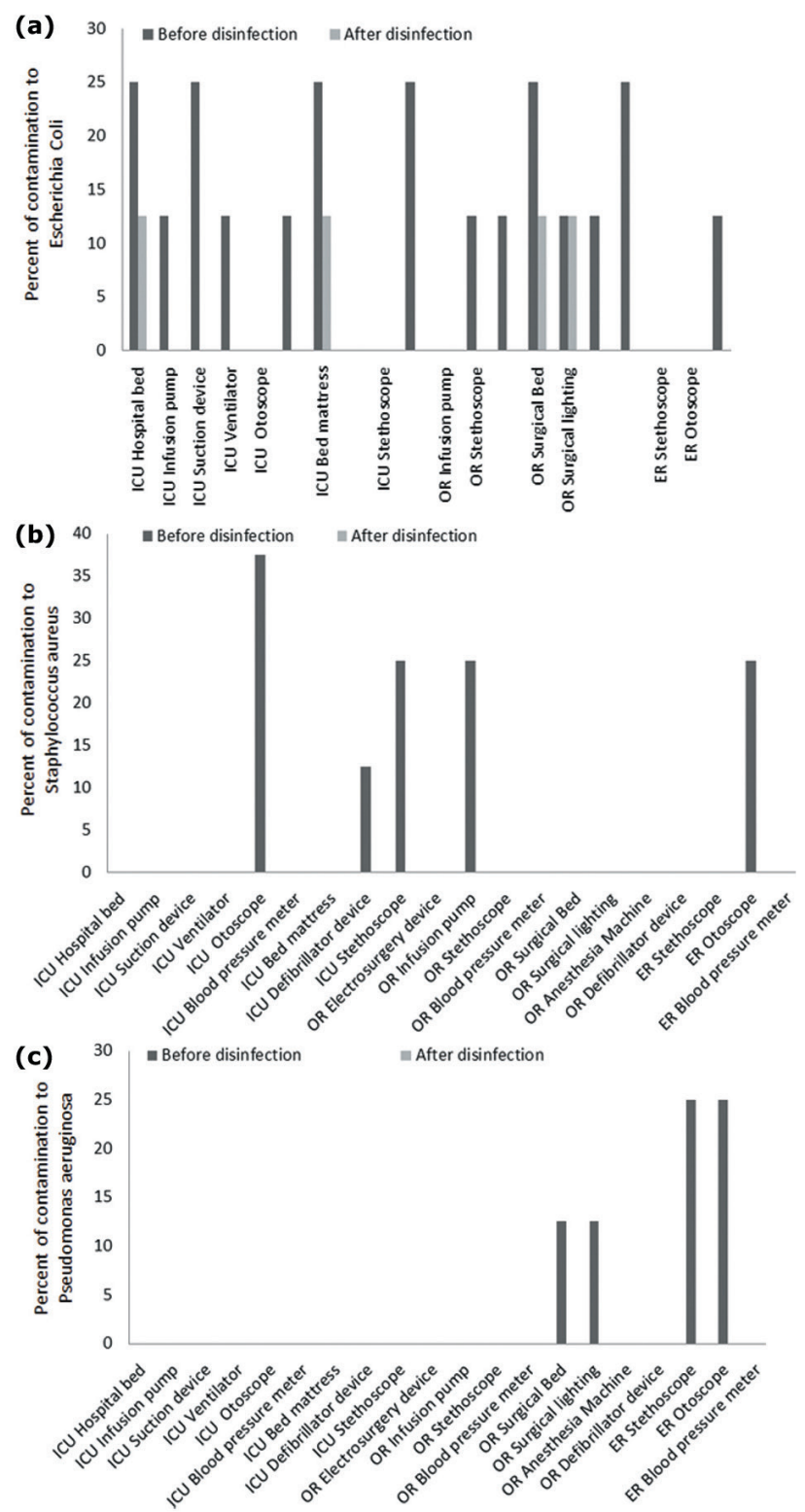

Figure 5 Percentage of growth of BaCteria Before AND AFTER DISINFECTION WITH THREE METHODS OF MC, HPV AND UV-C

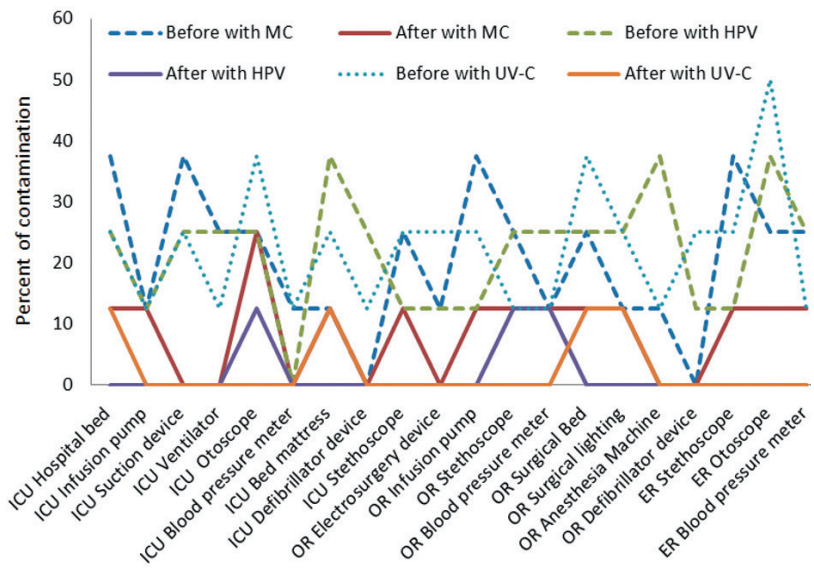

In these three instruments, the reason for the ineffectiveness of UV-C has been large dimensions and the height of these devices since UV-C radiation could not completely cover all the surface. For this reason, the results of the effectiveness of disinfection with UV-C method on the hospital bed and bed mattress in the ICU and surgical lighting in the operating room have been halved, compared to the HPV method. Also, this number for surgical beds in the operating room has been $66.67 \%$. On the other hand, in disinfection with HPV method, the contaminations of small devices such as otoscope and blood pressure meter which are usually in drawers are not completely removed. While, on the other hand, the UV-C method has been effective for disinfecting such devices. For example, for otoscope in the ICU, the effectiveness of disinfection with UV-C method has been 1.5 times of the HPV method. So, if moving portable UV-Cs all over the surfaces of these devices can be performed with correct programming so that the problem of UV-C coverage on devices with great dimensions such as beds and surgical lighting is solved, UV-C method would be more effective, efficient and appropriate than disinfection method with HPV.

\section{Study limitations and future works}

Although during the present study the operators have made every effort to perform the MC process uniformly and accurately and they have tried to clean the contamination from the equipment without hand and with suitable tissue, it is suggested in future studies to pay more attention to these concerns and be more focused in using MC before applying UV-C and HPV methods. Furthermore, an improved study design in the future will also bring significant statistical power. 


\section{Conclusion}

The purpose of the present study is future improvement in medical activities in key control points for detection of healthcare associated infections, such as intensive care, emergency room, operator block. Since the operator's inobservance and inaccurate implementation are possible, contamination can remain on the devices after MC method. If all preparations are observed, this method is merely suggested for disinfection of ventilator, defibrillator device, suction device and blood pressure meter in the ICU as well as electrosurgery device, anaesthesia machine and defibrillator device in the operating room. On the other hand, in disinfection with HPV method, the contaminations on small devices such as otoscope and blood pressure meter which are usually stored in drawers are not completely removed. But for disinfection of all devices except equipment of greater volume, such as beds and surgical lightings, the UV-C method is the best and most effective. The problem of disinfecting massive devices is solvable with correct programming of portable UV-C devices. These results can be helpful for policy making in regard to disinfection in hospitals, and the role of healthcare associated infections.

Acknowledgment: We thank the chairman and staff of APADANA hospital of Tehran for preparing the test equipment and their consultations about methods used.

Compliance with ethical standards: The authors declare they have no conflict of interest. This article does not contain any studies involving animals or human participants performed by any of the authors.

\section{Funding: None}

TABle 1. InVEStigating THE EFFECT OF MC METHOd ON THREE BACTERIA - EsCHERICHIA COLI, STAPHYLOCOCCUS AUREUS AND PSEUdOMONAS AERUGINOSA

\begin{tabular}{|c|c|c|c|c|c|c|c|c|c|c|}
\hline \multicolumn{3}{|c|}{ The growth of the bacteria after MC (CFUs) } & \multicolumn{3}{|c|}{ Control Strain(CFUs) } & \multirow{2}{*}{$\begin{array}{c}\text { The growth of } \\
\text { the bacteria } \\
\text { before MC } \\
\text { (CFUs) }\end{array}$} & \multirow{2}{*}{$\begin{array}{l}\text { number } \\
\text { of } \\
\text { samples }\end{array}$} & \multirow[b]{2}{*}{ Section } & \multirow[b]{2}{*}{ Equipment } & \multirow[b]{2}{*}{ Row } \\
\hline $\begin{array}{l}\text { Pseudomonas } \\
\text { aeruginosa }\end{array}$ & $\begin{array}{c}\text { Staphylococcus } \\
\text { aureus }\end{array}$ & $\begin{array}{c}\text { Escherichia } \\
\text { coli }\end{array}$ & $\begin{array}{c}\text { Pseudomonas } \\
\text { aeruginosa }\end{array}$ & $\begin{array}{c}\text { Staphylococcus } \\
\text { aureus }\end{array}$ & $\begin{array}{c}\text { Escherichia } \\
\text { coli }\end{array}$ & & & & & \\
\hline- & - & - & - & - & - & No growth & 1 & \multirow{8}{*}{$\mathrm{ICU}$} & \multirow{8}{*}{ Hospital bed } & \multirow{8}{*}{1} \\
\hline- & - & - & - & - & $\sqrt{ }$ & 30.000 & 2 & & & \\
\hline- & - & - & - & - & - & No growth & 3 & & & \\
\hline- & - & - & - & - & - & No growth & 4 & & & \\
\hline \multirow[t]{2}{*}{-} & - & - & - & $\sqrt{ }$ & - & 50.000 & 5 & & & \\
\hline & - & 30.000 & - & - & $\sqrt{ }$ & 30.000 & 6 & & & \\
\hline- & - & - & - & - & - & No growth & 7 & & & \\
\hline- & - & - & - & - & - & No growth & 8 & & & \\
\hline- & - & - & - & - & - & No growth & 1 & \multirow{8}{*}{$\mathrm{ICU}$} & \multirow{8}{*}{ Infusion pump } & \multirow{8}{*}{2} \\
\hline- & - & - & - & - & - & No growth & 2 & & & \\
\hline- & - & - & - & - & - & No growth & 3 & & & \\
\hline- & - & - & - & - & - & No growth & 4 & & & \\
\hline- & - & - & - & - & - & No growth & 5 & & & \\
\hline- & - & - & - & - & - & No growth & 6 & & & \\
\hline- & - & 50.000 & - & - & $\sqrt{ }$ & 50.000 & 7 & & & \\
\hline- & - & - & - & - & - & No growth & 8 & & & \\
\hline- & - & - & - & - & - & No growth & 1 & \multirow{8}{*}{ ICU } & \multirow{8}{*}{ Suction device } & \multirow{8}{*}{3} \\
\hline- & - & - & $\sqrt{ }$ & - & - & 50.000 & 2 & & & \\
\hline- & - & - & - & - & - & No growth & 3 & & & \\
\hline- & - & - & - & - & - & No growth & 4 & & & \\
\hline- & - & - & - & - & - & No growth & 5 & & & \\
\hline- & - & - & $\sqrt{ }$ & - & - & 50.000 & 6 & & & \\
\hline- & - & - & - & - & - & No growth & 7 & & & \\
\hline- & - & - & - & - & $\sqrt{ }$ & 30.000 & 8 & & & \\
\hline- & - & - & - & - & - & No growth & 1 & \multirow{4}{*}{ ICU } & \multirow{4}{*}{ Ventilator } & \multirow{4}{*}{4} \\
\hline- & - & - & - & - & - & No growth & 2 & & & \\
\hline- & - & - & - & - & - & No growth & 3 & & & \\
\hline- & - & - & - & - & $\sqrt{ }$ & 30.000 & 4 & & & \\
\hline
\end{tabular}




\begin{tabular}{|c|c|c|c|c|c|c|c|c|c|c|}
\hline \multicolumn{3}{|c|}{ The growth of the bacteria after MC (CFUs) } & \multicolumn{3}{|c|}{ Control Strain(CFUs) } & \multirow{2}{*}{$\begin{array}{l}\text { The growth of } \\
\text { the bacteria } \\
\text { before MC } \\
\text { (CFUs) }\end{array}$} & \multirow{2}{*}{$\begin{array}{c}\text { number } \\
\text { of } \\
\text { samples }\end{array}$} & \multirow[b]{2}{*}{ Section } & \multirow[b]{2}{*}{ Equipment } & \multirow[b]{2}{*}{ Row } \\
\hline $\begin{array}{c}\text { Pseudomonas } \\
\text { aeruginosa }\end{array}$ & $\begin{array}{l}\text { Staphylococcus } \\
\text { aureus }\end{array}$ & $\begin{array}{l}\text { Escherichia } \\
\text { coli }\end{array}$ & $\begin{array}{c}\text { Pseudomonas } \\
\text { aeruginosa }\end{array}$ & $\begin{array}{l}\text { Staphylococcus } \\
\text { aureus }\end{array}$ & $\begin{array}{c}\text { Escherichia } \\
\text { coli }\end{array}$ & & & & & \\
\hline- & - & - & - & - & - & No growth & 5 & & & \\
\hline- & - & - & - & - & - & No growth & 6 & & & \\
\hline- & - & - & - & - & - & No growth & 7 & & & \\
\hline- & - & - & - & - & $\sqrt{ }$ & 30.000 & 8 & & & \\
\hline \multirow[t]{2}{*}{-} & - & - & - & - & - & No growth & 1 & \multirow{8}{*}{ ICU } & \multirow{8}{*}{ Otoscope } & \multirow{8}{*}{5} \\
\hline & 50.000 & - & - & $\sqrt{ }$ & - & 50.000 & 2 & & & \\
\hline- & - & - & - & - & - & No growth & 3 & & & \\
\hline- & - & - & - & - & - & No growth & 4 & & & \\
\hline- & - & - & - & - & - & No growth & 5 & & & \\
\hline- & 50.000 & - & - & $\sqrt{ }$ & - & 50.000 & 6 & & & \\
\hline- & - & - & - & - & - & No growth & 7 & & & \\
\hline- & - & - & - & - & - & No growth & 8 & & & \\
\hline- & - & - & - & - & - & No growth & 1 & \multirow{8}{*}{ ICU } & \multirow{8}{*}{$\begin{array}{l}\text { Blood pressure } \\
\text { meter }\end{array}$} & \multirow{8}{*}{6} \\
\hline- & - & - & - & - & - & No growth & 2 & & & \\
\hline- & - & - & - & - & - & No growth & 3 & & & \\
\hline- & - & - & - & - & - & No growth & 4 & & & \\
\hline- & - & - & - & - & - & No growth & 5 & & & \\
\hline- & - & - & - & - & $\sqrt{ }$ & 30.000 & 6 & & & \\
\hline- & - & - & - & - & - & No growth & 7 & & & \\
\hline- & - & - & - & - & - & No growth & 8 & & & \\
\hline- & - & - & - & - & - & No growth & 1 & \multirow{8}{*}{ ICU } & \multirow{8}{*}{ Bed mattress } & \multirow{8}{*}{7} \\
\hline- & - & - & - & - & - & No growth & 2 & & & \\
\hline- & - & - & - & - & - & No growth & 3 & & & \\
\hline- & 30.000 & - & - & $\sqrt{ }$ & - & 30.000 & 4 & & & \\
\hline- & - & - & - & - & - & No growth & 5 & & & \\
\hline- & - & - & - & - & - & No growth & 6 & & & \\
\hline- & - & - & - & - & - & No growth & 7 & & & \\
\hline- & - & - & - & - & - & No growth & 8 & & & \\
\hline- & - & - & - & - & - & No growth & 1 & \multirow{8}{*}{$\mathrm{ICU}$} & & \\
\hline- & - & - & - & - & - & No growth & 2 & & & \\
\hline- & - & - & - & - & - & No growth & 3 & & & \\
\hline- & - & - & - & - & - & No growth & 4 & & Defibrillator & 8 \\
\hline- & - & - & - & - & - & No growth & 5 & & device & 0 \\
\hline- & - & - & - & - & - & No growth & 6 & & & \\
\hline- & - & - & - & - & - & No growth & 7 & & & \\
\hline- & - & - & - & - & - & No growth & 8 & & & \\
\hline- & - & - & - & - & - & No growth & 1 & & & \\
\hline- & - & - & - & $\sqrt{ }$ & - & 50.000 & 2 & & & \\
\hline- & - & - & - & - & - & No growth & 3 & & & \\
\hline- & - & - & - & - & - & No growth & 4 & ICU & Stethoscone & 9 \\
\hline- & - & - & - & - & - & No growth & 5 & & setnoscope & \\
\hline- & 30.000 & - & - & $\sqrt{ }$ & - & 50.000 & 6 & & & \\
\hline- & - & - & - & - & - & No growth & 7 & & & \\
\hline- & - & - & - & - & - & No growth & 8 & & & \\
\hline- & - & - & - & - & - & No growth & 1 & & & \\
\hline- & - & - & - & - & - & No growth & 2 & & & \\
\hline- & - & - & - & - & - & No growth & 3 & OR & $\begin{array}{c}\text { Electrosurgery } \\
\text { device }\end{array}$ & 10 \\
\hline- & - & - & - & - & - & No growth & 4 & & & \\
\hline- & - & - & - & - & - & No growth & 5 & & & \\
\hline
\end{tabular}




\begin{tabular}{|c|c|c|c|c|c|c|c|c|c|c|}
\hline \multicolumn{3}{|c|}{ The growth of the bacteria after MC (CFUs) } & \multicolumn{3}{|c|}{ Control Strain(CFUs) } & \multirow{2}{*}{$\begin{array}{c}\text { The growth of } \\
\text { the bacteria } \\
\text { before MC } \\
\text { (CFUs) }\end{array}$} & \multirow{2}{*}{$\begin{array}{c}\text { number } \\
\text { of } \\
\text { samples }\end{array}$} & \multirow[b]{2}{*}{ Section } & \multirow[b]{2}{*}{ Equipment } & \multirow[b]{2}{*}{ Row } \\
\hline $\begin{array}{c}\text { Pseudomonas } \\
\text { aeruginosa }\end{array}$ & $\begin{array}{c}\text { Staphylococcus } \\
\text { aureus }\end{array}$ & $\begin{array}{c}\text { Escherichia } \\
\text { coli }\end{array}$ & $\begin{array}{c}\text { Pseudomonas } \\
\text { aeruginosa }\end{array}$ & $\begin{array}{c}\text { Staphylococcus } \\
\text { aureus }\end{array}$ & $\begin{array}{c}\text { Escherichia } \\
\text { coli }\end{array}$ & & & & & \\
\hline- & - & - & - & - & - & No growth & 6 & & & \\
\hline- & - & - & - & $\sqrt{ }$ & - & 30.000 & 7 & & & \\
\hline- & - & - & - & - & - & No growth & 8 & & & \\
\hline- & - & - & - & - & $\sqrt{ }$ & 50.000 & 1 & \multirow{8}{*}{ OR } & \multirow{8}{*}{ Infusion pump } & \multirow{8}{*}{11} \\
\hline- & - & - & - & - & - & No growth & 2 & & & \\
\hline- & - & - & - & - & - & No growth & 3 & & & \\
\hline- & - & - & $\sqrt{ }$ & - & - & 30.000 & 4 & & & \\
\hline- & - & - & - & - & - & No growth & 5 & & & \\
\hline- & - & - & - & - & - & No growth & 6 & & & \\
\hline- & - & 30.000 & & - & $\sqrt{ }$ & 30.000 & 7 & & & \\
\hline- & - & - & - & - & - & No growth & 8 & & & \\
\hline- & - & - & - & - & $\sqrt{ }$ & 30.000 & 1 & \multirow{8}{*}{ OR } & \multirow{8}{*}{ Stethoscope } & \multirow{8}{*}{12} \\
\hline- & - & - & - & - & - & No growth & 2 & & & \\
\hline- & - & 30.000 & - & - & $\sqrt{ }$ & 30.000 & 3 & & & \\
\hline- & - & - & - & - & - & No growth & 4 & & & \\
\hline- & - & - & - & - & - & No growth & 5 & & & \\
\hline- & - & - & - & - & - & No growth & 6 & & & \\
\hline- & - & - & - & - & - & No growth & 7 & & & \\
\hline- & - & - & - & - & - & No growth & 8 & & & \\
\hline- & - & - & - & - & - & No growth & 1 & \multirow{8}{*}{ OR } & \multirow{8}{*}{$\begin{array}{c}\text { Blood pressure } \\
\text { meter }\end{array}$} & \multirow{8}{*}{13} \\
\hline- & - & - & - & - & - & No growth & 2 & & & \\
\hline- & - & - & - & - & - & No growth & 3 & & & \\
\hline- & - & - & - & - & - & No growth & 4 & & & \\
\hline- & 50.000 & - & - & $\sqrt{ }$ & - & 50.000 & 5 & & & \\
\hline- & - & - & - & - & - & No growth & 6 & & & \\
\hline- & - & - & - & - & - & No growth & 7 & & & \\
\hline- & - & - & - & - & - & No growth & 8 & & & \\
\hline- & - & - & - & - & - & No growth & 1 & \multirow{8}{*}{ OR } & \multirow{8}{*}{ Surgical Bed } & \\
\hline- & - & - & - & - & $\sqrt{ }$ & 30.000 & 2 & & & \\
\hline- & - & - & - & - & - & No growth & 3 & & & \\
\hline- & - & - & - & - & - & No growth & 4 & & & 14 \\
\hline- & - & 30.000 & - & - & $\sqrt{ }$ & 30.000 & 5 & & & 14 \\
\hline- & - & - & - & - & - & No growth & 6 & & & \\
\hline- & - & - & - & - & - & No growth & 7 & & & \\
\hline- & - & - & - & - & - & No growth & 8 & & & \\
\hline- & - & 30.000 & - & - & $\sqrt{ }$ & 30.000 & 1 & & & \\
\hline- & - & - & - & - & - & No growth & 2 & & & \\
\hline- & - & - & - & - & - & No growth & 3 & & & \\
\hline- & - & - & - & - & - & No growth & 4 & $\mathrm{OR}$ & Surgical lighting & 15 \\
\hline- & - & - & - & - & - & No growth & 5 & OK & surgical lighting & 15 \\
\hline- & - & - & - & - & - & No growth & 6 & & & \\
\hline- & - & - & - & - & - & No growth & 7 & & & \\
\hline- & - & - & - & - & - & No growth & 8 & & & \\
\hline- & - & - & - & - & - & No growth & 1 & & & \\
\hline- & - & - & - & - & - & No growth & 2 & & & \\
\hline- & - & - & - & - & - & No growth & 3 & & Anesthesia & 16 \\
\hline- & - & - & - & - & $\sqrt{ }$ & 30.000 & 4 & OR & Machine & 16 \\
\hline- & - & - & - & - & - & No growth & 5 & & & \\
\hline- & - & - & - & - & - & No growth & 6 & & & \\
\hline
\end{tabular}




\begin{tabular}{|c|c|c|c|c|c|c|c|c|c|c|}
\hline \multicolumn{3}{|c|}{ The growth of the bacteria after MC (CFUs) } & \multicolumn{3}{|c|}{ Control Strain(CFUs) } & \multirow{2}{*}{$\begin{array}{l}\text { The growth of } \\
\text { the bacteria } \\
\text { before MC } \\
\text { (CFUs) }\end{array}$} & \multirow{2}{*}{$\begin{array}{c}\text { number } \\
\text { of } \\
\text { samples }\end{array}$} & \multirow[b]{2}{*}{ Section } & \multirow[b]{2}{*}{ Equipment } & \multirow[b]{2}{*}{ Row } \\
\hline $\begin{array}{c}\text { Pseudomonas } \\
\text { aeruginosa }\end{array}$ & $\begin{array}{l}\text { Staphylococcus } \\
\text { aureus }\end{array}$ & $\begin{array}{c}\text { Escherichia } \\
\text { coli }\end{array}$ & $\begin{array}{c}\text { Pseudomonas } \\
\text { aeruginosa }\end{array}$ & $\begin{array}{l}\text { Staphylococcus } \\
\text { aureus }\end{array}$ & $\begin{array}{c}\text { Escherichia } \\
\text { coli }\end{array}$ & & & & & \\
\hline- & - & - & - & - & - & No growth & 7 & & & \\
\hline- & - & - & - & - & - & No growth & 8 & & & \\
\hline- & - & - & - & - & - & No growth & 1 & \multirow{8}{*}{ OR } & \multirow{8}{*}{$\begin{array}{c}\text { Defibrillator } \\
\text { device }\end{array}$} & \multirow{8}{*}{17} \\
\hline- & - & - & - & - & - & No growth & 2 & & & \\
\hline- & - & - & - & - & - & No growth & 3 & & & \\
\hline- & - & - & - & - & - & No growth & 4 & & & \\
\hline- & - & - & - & - & - & No growth & 5 & & & \\
\hline- & - & - & - & - & - & No growth & 6 & & & \\
\hline- & - & - & - & - & - & No growth & 7 & & & \\
\hline- & - & - & - & - & - & No growth & 8 & & & \\
\hline- & - & - & - & - & - & No growth & 1 & \multirow{8}{*}{ ER } & \multirow{8}{*}{ Stethoscope } & \multirow{8}{*}{18} \\
\hline- & - & - & - & $\sqrt{ }$ & - & 50.000 & 2 & & & \\
\hline- & - & - & - & - & - & No growth & 3 & & & \\
\hline- & 30.000 & - & - & $\sqrt{ }$ & - & 50.000 & 4 & & & \\
\hline- & - & - & - & - & - & No growth & 5 & & & \\
\hline- & - & - & - & - & - & No growth & 6 & & & \\
\hline- & - & - & - & - & - & No growth & 7 & & & \\
\hline- & - & - & - & $\sqrt{ }$ & - & 30.000 & 8 & & & \\
\hline- & - & - & - & $\sqrt{ }$ & - & 50.000 & 1 & \multirow{8}{*}{ ER } & \multirow{8}{*}{ Otoscope } & \multirow{8}{*}{19} \\
\hline- & - & - & - & - & - & No growth & 2 & & & \\
\hline- & - & - & - & - & - & No growth & 3 & & & \\
\hline- & - & - & - & - & - & No growth & 4 & & & \\
\hline- & - & - & - & - & - & No growth & 5 & & & \\
\hline- & 30.000 & - & - & $\sqrt{ }$ & - & 50.000 & 6 & & & \\
\hline- & - & - & - & - & - & No growth & 7 & & & \\
\hline- & - & - & - & - & - & No growth & 8 & & & \\
\hline- & - & - & - & - & - & No growth & 1 & \multirow{8}{*}{ ER } & \multirow{8}{*}{$\begin{array}{l}\text { Blood pressure } \\
\text { meter }\end{array}$} & \multirow{8}{*}{20} \\
\hline- & - & 30.000 & - & - & $\sqrt{ }$ & 30.000 & 2 & & & \\
\hline- & - & - & - & - & - & No growth & 3 & & & \\
\hline- & - & - & - & - & - & No growth & 4 & & & \\
\hline- & - & - & - & - & - & No growth & 5 & & & \\
\hline- & - & - & - & - & - & No growth & 6 & & & \\
\hline- & - & - & - & - & $\sqrt{ }$ & 30.000 & 7 & & & \\
\hline- & - & - & - & - & - & No growth & 8 & & & \\
\hline
\end{tabular}

TABLE 2. INVESTIGATING THE EFFECT OF HPV METHOD ON THREE BACTERIA - ESCHERICHIA COLI, STAPHYLOCOCCUS AUREUS AND PSEUdomonas AERUGINOSA

\begin{tabular}{|c|c|c|c|c|c|c|c|c|c|c|}
\hline \multicolumn{3}{|c|}{ The growth of the bacteria after HPV (CFUs) } & \multicolumn{3}{|c|}{ Control Strain(CFUs) } & \multirow{2}{*}{$\begin{array}{l}\text { The growth of } \\
\text { the bacteria } \\
\text { before HPV } \\
\text { (CFUs) }\end{array}$} & \multirow{2}{*}{$\begin{array}{c}\text { number } \\
\text { of } \\
\text { samples }\end{array}$} & \multirow[b]{2}{*}{ Section } & \multirow[b]{2}{*}{ Equipment } & \multirow[b]{2}{*}{ Row } \\
\hline $\begin{array}{c}\text { Pseudomonas } \\
\text { aeruginosa }\end{array}$ & $\begin{array}{c}\text { Staphylococcus } \\
\text { aureus }\end{array}$ & $\begin{array}{c}\text { Escherichia } \\
\text { coli }\end{array}$ & $\begin{array}{c}\text { Pseudomonas } \\
\text { aeruginosa }\end{array}$ & $\begin{array}{c}\text { Staphylococcus } \\
\text { aureus }\end{array}$ & $\begin{array}{c}\text { Escherichia } \\
\text { coli }\end{array}$ & & & & & \\
\hline- & - & - & - & - & - & No growth & 1 & \multirow{8}{*}{$\mathrm{ICU}$} & \multirow{8}{*}{ Hospital bed } & \multirow{8}{*}{1} \\
\hline- & - & - & - & - & $\sqrt{ }$ & 30.000 & 2 & & & \\
\hline- & - & - & - & & - & No growth & 3 & & & \\
\hline- & - & - & - & - & - & No growth & 4 & & & \\
\hline- & - & - & - & - & - & No growth & 5 & & & \\
\hline- & - & - & - & - & - & No growth & 6 & & & \\
\hline- & - & - & - & - & $\sqrt{ }$ & 50.000 & 7 & & & \\
\hline- & - & - & - & - & - & No growth & 8 & & & \\
\hline
\end{tabular}




\begin{tabular}{|c|c|c|c|c|c|c|c|c|c|c|}
\hline \multicolumn{3}{|c|}{ The growth of the bacteria after HPV (CFUs) } & \multicolumn{3}{|c|}{ Control Strain(CFUs) } & \multirow{2}{*}{$\begin{array}{c}\text { The growth of } \\
\text { the bacteria } \\
\text { before HPV } \\
\text { (CFUs) }\end{array}$} & \multirow{2}{*}{$\begin{array}{c}\text { number } \\
\text { of } \\
\text { samples }\end{array}$} & \multirow[b]{2}{*}{ Section } & \multirow[b]{2}{*}{ Equipment } & \multirow[b]{2}{*}{ Row } \\
\hline $\begin{array}{l}\text { Pseudomonas } \\
\text { aeruginosa }\end{array}$ & $\begin{array}{c}\text { Staphylococcus } \\
\text { aureus }\end{array}$ & $\begin{array}{c}\text { Escherichia } \\
\text { coli }\end{array}$ & $\begin{array}{c}\text { Pseudomonas } \\
\text { aeruginosa }\end{array}$ & $\begin{array}{c}\text { Staphylococcus } \\
\text { aureus }\end{array}$ & $\begin{array}{c}\text { Escherichia } \\
\text { coli }\end{array}$ & & & & & \\
\hline- & - & - & - & - & - & No growth & 1 & \multirow{8}{*}{$\mathrm{ICU}$} & \multirow{8}{*}{ Infusion pump } & \multirow{8}{*}{2} \\
\hline- & - & - & - & - & - & No growth & 2 & & & \\
\hline- & - & - & $\sqrt{ }$ & - & - & 30.000 & 3 & & & \\
\hline- & - & - & - & - & - & No growth & 4 & & & \\
\hline- & - & - & - & - & - & No growth & 5 & & & \\
\hline- & - & - & - & - & - & No growth & 6 & & & \\
\hline- & - & - & - & - & - & No growth & 7 & & & \\
\hline- & - & - & - & - & - & No growth & 8 & & & \\
\hline- & - & - & - & - & - & No growth & 1 & \multirow{8}{*}{ ICU } & \multirow{8}{*}{ Suction device } & \multirow{8}{*}{3} \\
\hline- & - & - & - & - & - & No growth & 2 & & & \\
\hline- & - & - & - & $\sqrt{ }$ & - & 30.000 & 3 & & & \\
\hline- & - & - & - & - & - & No growth & 4 & & & \\
\hline- & - & - & - & - & - & No growth & 5 & & & \\
\hline- & - & - & - & $\sqrt{ }$ & - & 30.000 & 6 & & & \\
\hline- & - & - & - & - & - & No growth & 7 & & & \\
\hline- & - & - & - & - & - & No growth & 8 & & & \\
\hline- & - & - & - & - & - & No growth & 1 & \multirow{8}{*}{$\mathrm{ICU}$} & \multirow{8}{*}{ Ventilator } & \multirow{8}{*}{4} \\
\hline- & - & - & - & - & - & No growth & 2 & & & \\
\hline- & - & - & - & $\sqrt{ }$ & - & 50.000 & 3 & & & \\
\hline- & - & - & - & - & - & No growth & 4 & & & \\
\hline- & - & - & - & - & - & No growth & 5 & & & \\
\hline- & - & - & $\sqrt{ }$ & - & - & 30.000 & 6 & & & \\
\hline- & - & - & - & - & - & No growth & 7 & & & \\
\hline- & - & - & - & - & - & No growth & 8 & & & \\
\hline- & - & - & - & - & - & No growth & 1 & \multirow{8}{*}{$\mathrm{ICU}$} & \multirow{8}{*}{ Otoscope } & \multirow{8}{*}{5} \\
\hline- & - & - & - & - & - & No growth & 2 & & & \\
\hline- & - & - & - & - & - & No growth & 3 & & & \\
\hline- & 30.000 & - & - & $\sqrt{ }$ & - & 30.000 & 4 & & & \\
\hline- & - & - & - & - & - & No growth & 5 & & & \\
\hline- & - & - & - & - & - & No growth & 6 & & & \\
\hline- & - & - & - & $\sqrt{ }$ & - & 30.000 & 7 & & & \\
\hline- & - & - & - & - & - & No growth & 8 & & & \\
\hline- & - & - & - & - & - & No growth & 1 & & & \\
\hline- & - & - & - & - & - & No growth & 2 & & & \\
\hline- & - & - & - & - & - & No growth & 3 & & & \\
\hline- & - & - & - & - & - & No growth & 4 & $\mathrm{ICU}$ & Blood pressure & 6 \\
\hline- & - & - & - & - & - & No growth & 5 & ICU & meter & 6 \\
\hline- & - & - & - & - & - & No growth & 6 & & & \\
\hline- & - & - & - & - & - & No growth & 7 & & & \\
\hline- & - & - & - & - & - & No growth & 8 & & & \\
\hline- & - & - & - & - & $\sqrt{ }$ & 30.000 & 1 & & & \\
\hline- & - & - & - & - & - & No growth & 2 & & & \\
\hline- & - & - & - & - & - & No growth & 3 & & & \\
\hline- & - & - & - & - & - & No growth & 4 & ICU & Bed mattress & 7 \\
\hline- & - & - & $\sqrt{ }$ & - & - & 30.000 & 5 & ICU & Bed mattress & 1 \\
\hline- & - & - & - & - & $\sqrt{ }$ & 50.000 & 6 & & & \\
\hline- & - & - & - & - & - & No growth & 7 & & & \\
\hline- & - & - & - & - & - & No growth & 8 & & & \\
\hline
\end{tabular}




\begin{tabular}{|c|c|c|c|c|c|c|c|c|c|c|}
\hline \multicolumn{3}{|c|}{ The growth of the bacteria after HPV (CFUs) } & \multicolumn{3}{|c|}{ Control Strain(CFUs) } & \multirow{2}{*}{$\begin{array}{c}\text { The growth of } \\
\text { the bacteria } \\
\text { before HPV } \\
\text { (CFUs) }\end{array}$} & \multirow{2}{*}{$\begin{array}{c}\text { number } \\
\text { of } \\
\text { samples }\end{array}$} & \multirow[b]{2}{*}{ Section } & \multirow[b]{2}{*}{ Equipment } & \multirow[b]{2}{*}{ Row } \\
\hline $\begin{array}{c}\text { Pseudomonas } \\
\text { aeruginosa }\end{array}$ & $\begin{array}{c}\text { Staphylococcus } \\
\text { aureus }\end{array}$ & $\begin{array}{c}\text { Escherichia } \\
\text { coli }\end{array}$ & $\begin{array}{c}\text { Pseudomonas } \\
\text { aeruginosa }\end{array}$ & $\begin{array}{c}\text { Staphylococcus } \\
\text { aureus }\end{array}$ & $\begin{array}{c}\text { Escherichia } \\
\text { coli }\end{array}$ & & & & & \\
\hline- & - & - & - & - & - & No growth & 1 & \multirow{8}{*}{ ICU } & \multirow{8}{*}{$\begin{array}{c}\text { Defibrillator } \\
\text { device }\end{array}$} & \multirow{8}{*}{8} \\
\hline- & - & - & - & - & $\sqrt{ }$ & 30.000 & 2 & & & \\
\hline- & - & - & - & - & - & No growth & 3 & & & \\
\hline- & - & - & - & - & - & No growth & 4 & & & \\
\hline- & - & - & - & - & $\sqrt{ }$ & 30.000 & 5 & & & \\
\hline- & - & - & - & - & - & No growth & 6 & & & \\
\hline- & - & - & - & - & - & No growth & 7 & & & \\
\hline- & - & - & - & - & - & No growth & 8 & & & \\
\hline - & - & - & - & - & - & No growth & 1 & \multirow{8}{*}{ ICU } & \multirow{8}{*}{ Stethoscope } & \multirow{8}{*}{9} \\
\hline- & - & - & - & - & - & No growth & 2 & & & \\
\hline- & - & - & - & - & - & No growth & 3 & & & \\
\hline- & - & - & - & - & - & No growth & 4 & & & \\
\hline- & - & - & - & - & - & No growth & 5 & & & \\
\hline- & - & - & - & - & - & No growth & 6 & & & \\
\hline- & - & - & - & $\sqrt{ }$ & - & 50.000 & 7 & & & \\
\hline- & - & - & - & - & - & No growth & 8 & & & \\
\hline- & - & - & - & - & - & No growth & 1 & \multirow{8}{*}{ OR } & \multirow{8}{*}{$\begin{array}{c}\text { Electrosurgery } \\
\text { device }\end{array}$} & \multirow{8}{*}{10} \\
\hline- & - & - & - & - & - & No growth & 2 & & & \\
\hline- & - & - & - & - & - & No growth & 3 & & & \\
\hline - & - & - & - & - & - & No growth & 4 & & & \\
\hline- & - & - & - & - & - & No growth & 5 & & & \\
\hline- & - & - & - & - & $\sqrt{ }$ & 30.000 & 6 & & & \\
\hline- & - & - & - & - & - & No growth & 7 & & & \\
\hline- & - & - & - & - & - & No growth & 8 & & & \\
\hline- & - & - & - & - & - & No growth & 1 & \multirow{8}{*}{ OR } & \multirow{8}{*}{ Infusion pump } & \multirow{8}{*}{11} \\
\hline- & - & - & - & - & - & No growth & 2 & & & \\
\hline- & - & - & - & - & - & No growth & 3 & & & \\
\hline- & - & - & - & - & $\sqrt{ }$ & 30.000 & 4 & & & \\
\hline- & - & - & - & - & - & No growth & 5 & & & \\
\hline- & - & - & - & - & - & No growth & 6 & & & \\
\hline- & - & - & - & - & - & No growth & 7 & & & \\
\hline- & - & - & - & - & - & No growth & 8 & & & \\
\hline- & - & - & - & - & - & No growth & 1 & & & \\
\hline- & - & 30.000 & - & - & $\sqrt{ }$ & 30.000 & 2 & & & \\
\hline- & - & - & - & - & - & No growth & 3 & & & \\
\hline- & - & - & - & - & - & No growth & 4 & & & \\
\hline- & - & - & - & - & $\sqrt{ }$ & 30.000 & 5 & OR & Stethoscope & 12 \\
\hline- & - & - & - & - & - & No growth & 6 & & & \\
\hline- & - & - & - & - & - & No growth & 7 & & & \\
\hline- & - & - & - & - & - & No growth & 8 & & & \\
\hline- & - & - & - & - & - & No growth & 1 & & & \\
\hline- & - & - & - & - & - & No growth & 2 & & & \\
\hline- & - & - & - & - & - & No growth & 3 & & & \\
\hline- & - & - & - & - & $\sqrt{ }$ & 50.000 & 4 & OR & Blood pressure & 13 \\
\hline- & - & - & - & - & - & No growth & 5 & OR & meter & \\
\hline- & - & - & - & - & - & No growth & 6 & & & \\
\hline- & - & - & - & - & - & No growth & 7 & & & \\
\hline- & - & 50.000 & - & - & $\sqrt{ }$ & 50.000 & 8 & & & \\
\hline
\end{tabular}




\begin{tabular}{|c|c|c|c|c|c|c|c|c|c|c|}
\hline \multicolumn{3}{|c|}{ The growth of the bacteria after HPV (CFUs) } & \multicolumn{3}{|c|}{ Control Strain(CFUs) } & \multirow{2}{*}{$\begin{array}{c}\text { The growth of } \\
\text { the bacteria } \\
\text { before HPV } \\
\text { (CFUs) }\end{array}$} & \multirow{2}{*}{$\begin{array}{c}\text { number } \\
\text { of } \\
\text { samples }\end{array}$} & \multirow[b]{2}{*}{ Section } & \multirow[b]{2}{*}{ Equipment } & \multirow[b]{2}{*}{ Row } \\
\hline $\begin{array}{c}\text { Pseudomonas } \\
\text { aeruginosa }\end{array}$ & $\begin{array}{c}\text { Staphylococcus } \\
\text { aureus }\end{array}$ & $\begin{array}{c}\text { Escherichia } \\
\text { coli }\end{array}$ & $\begin{array}{c}\text { Pseudomonas } \\
\text { aeruginosa }\end{array}$ & $\begin{array}{c}\text { Staphylococcus } \\
\text { aureus }\end{array}$ & $\begin{array}{c}\text { Escherichia } \\
\text { coli }\end{array}$ & & & & & \\
\hline- & - & - & - & - & - & No growth & 1 & \multirow{8}{*}{ OR } & \multirow{8}{*}{ Surgical Bed } & \multirow{8}{*}{14} \\
\hline- & - & - & - & - & $\sqrt{ }$ & 30.000 & 2 & & & \\
\hline- & - & - & - & - & - & No growth & 3 & & & \\
\hline- & - & - & - & - & - & No growth & 4 & & & \\
\hline- & - & - & - & - & $\sqrt{ }$ & 30.000 & 5 & & & \\
\hline- & - & - & - & - & - & No growth & 6 & & & \\
\hline- & - & - & - & - & - & No growth & 7 & & & \\
\hline- & - & - & - & - & - & No growth & 8 & & & \\
\hline- & - & - & - & - & - & No growth & 1 & \multirow{8}{*}{ OR } & \multirow{8}{*}{$\begin{array}{l}\text { Surgical } \\
\text { lighting }\end{array}$} & \multirow{8}{*}{15} \\
\hline- & - & - & - & - & - & No growth & 2 & & & \\
\hline- & - & - & - & - & $\sqrt{ }$ & 50.000 & 3 & & & \\
\hline- & - & - & - & - & - & No growth & 4 & & & \\
\hline- & - & - & - & - & - & No growth & 5 & & & \\
\hline- & - & - & - & - & $\sqrt{ }$ & 30.000 & 6 & & & \\
\hline- & - & - & - & - & - & No growth & 7 & & & \\
\hline- & - & - & - & - & - & No growth & 8 & & & \\
\hline- & - & - & - & - & - & No growth & 1 & \multirow{8}{*}{ OR } & \multirow{8}{*}{$\begin{array}{c}\text { Anesthesia } \\
\text { Machine }\end{array}$} & \multirow{8}{*}{16} \\
\hline- & - & - & - & - & $\sqrt{ }$ & 30.000 & 2 & & & \\
\hline- & - & - & - & - & - & No growth & 3 & & & \\
\hline- & - & - & - & - & - & No growth & 4 & & & \\
\hline- & - & - & - & $\sqrt{ }$ & - & 30.000 & 5 & & & \\
\hline- & - & - & - & - & - & No growth & 6 & & & \\
\hline- & - & - & - & - & - & No growth & 7 & & & \\
\hline- & - & - & - & - & $\sqrt{ }$ & 50.000 & 8 & & & \\
\hline- & - & - & - & - & - & No growth & 1 & \multirow{8}{*}{ OR } & \multirow{8}{*}{$\begin{array}{c}\text { Defibrillator } \\
\text { device }\end{array}$} & \multirow{8}{*}{17} \\
\hline- & - & - & - & - & - & No growth & 2 & & & \\
\hline- & - & - & - & - & - & No growth & 3 & & & \\
\hline- & - & - & - & - & $\sqrt{ }$ & 30.000 & 4 & & & \\
\hline- & - & - & - & - & - & No growth & 5 & & & \\
\hline- & - & - & - & - & - & No growth & 6 & & & \\
\hline- & - & - & - & - & - & No growth & 7 & & & \\
\hline- & - & - & - & - & - & No growth & 8 & & & \\
\hline- & - & - & - & - & - & No growth & 1 & & & \\
\hline- & - & - & - & - & - & No growth & 2 & & & \\
\hline- & - & - & - & - & - & No growth & 3 & & & \\
\hline- & - & - & - & - & - & No growth & 4 & $\mathrm{ER}$ & Stethoscone & 18 \\
\hline- & - & - & - & - & - & No growth & 5 & EK & Stetnoscope & 18 \\
\hline- & - & - & - & - & - & No growth & 6 & & & \\
\hline- & - & - & - & - & $\sqrt{ }$ & 30.000 & 7 & & & \\
\hline- & - & - & - & - & - & No growth & 8 & & & \\
\hline- & - & - & - & - & - & No growth & 1 & & & \\
\hline- & - & - & - & $\sqrt{ }$ & - & 30.000 & 2 & & & \\
\hline- & - & - & - & - & - & No growth & 3 & & & \\
\hline- & - & - & - & - & - & No growth & 4 & & & 19 \\
\hline- & - & - & - & $\sqrt{ }$ & - & 30.000 & 5 & ER & Utoscope & 19 \\
\hline- & - & - & - & - & - & No growth & 6 & & & \\
\hline- & - & - & - & - & $\sqrt{ }$ & 30.000 & 7 & & & \\
\hline- & - & - & - & - & - & No growth & 8 & & & \\
\hline
\end{tabular}




\begin{tabular}{|c|c|c|c|c|c|c|c|c|c|c|}
\hline \multicolumn{3}{|c|}{ The growth of the bacteria after HPV (CFUs) } & \multicolumn{3}{|c|}{ Control Strain(CFUs) } & \multirow{2}{*}{$\begin{array}{l}\text { The growth of } \\
\text { the bacteria } \\
\text { before HPV } \\
\text { (CFUs) }\end{array}$} & \multirow{2}{*}{$\begin{array}{c}\text { number } \\
\text { of } \\
\text { samples }\end{array}$} & \multirow[b]{2}{*}{ Section } & \multirow[b]{2}{*}{ Equipment } & \multirow[b]{2}{*}{ Row } \\
\hline $\begin{array}{c}\text { Pseudomonas } \\
\text { aeruginosa }\end{array}$ & $\begin{array}{c}\text { Staphylococcus } \\
\text { aureus }\end{array}$ & $\begin{array}{l}\text { Escherichia } \\
\text { coli }\end{array}$ & $\begin{array}{c}\text { Pseudomonas } \\
\text { aeruginosa }\end{array}$ & $\begin{array}{l}\text { Staphylococcus } \\
\text { aureus }\end{array}$ & $\begin{array}{c}\text { Escherichia } \\
\text { coli }\end{array}$ & & & & & \\
\hline- & - & - & - & - & - & No growth & 1 & \multirow{8}{*}{ ER } & \multirow{8}{*}{$\begin{array}{c}\text { Blood pressure } \\
\text { meter }\end{array}$} & \multirow{8}{*}{20} \\
\hline- & - & 30.000 & - & - & $\sqrt{ }$ & 50.000 & 2 & & & \\
\hline- & - & - & - & - & - & No growth & 3 & & & \\
\hline- & - & - & - & - & - & No growth & 4 & & & \\
\hline- & - & - & - & - & $\sqrt{ }$ & 30.000 & 5 & & & \\
\hline- & - & - & - & - & - & No growth & 6 & & & \\
\hline- & - & - & - & - & - & No growth & 7 & & & \\
\hline- & - & - & - & - & - & No growth & 8 & & & \\
\hline
\end{tabular}

TABle 3. INVESTIGATING THE EFFECT OF UV-C METHOD ON THREE BACTERIA - ESCHERICHIA COLI, STAPHYLOCOCCUS AUREUS AND PSEUdOMONAS AERUGINOSA

\begin{tabular}{|c|c|c|c|c|c|c|c|c|c|c|}
\hline \multicolumn{3}{|c|}{ The growth of the bacteria after UV-C (CFUs) } & \multicolumn{3}{|c|}{ Control Strain(CFUs) } & \multirow{2}{*}{$\begin{array}{l}\text { The growth of } \\
\text { the bacteria } \\
\text { before UV-C } \\
\text { (CFUs) }\end{array}$} & \multirow{2}{*}{\begin{tabular}{|c|}
$\begin{array}{c}\text { number } \\
\text { of } \\
\text { samples }\end{array}$ \\
\end{tabular}} & \multirow[b]{2}{*}{ Section } & \multirow[b]{2}{*}{ Equipment } & \multirow[b]{2}{*}{ Row } \\
\hline $\begin{array}{c}\text { Pseudomonas } \\
\text { aeruginosa }\end{array}$ & $\begin{array}{c}\text { Staphylococcus } \\
\text { aureus }\end{array}$ & $\begin{array}{l}\text { Escherichia } \\
\text { coli }\end{array}$ & $\begin{array}{c}\text { Pseudomonas } \\
\text { aeruginosa }\end{array}$ & $\begin{array}{c}\text { Staphylococcus } \\
\text { aureus }\end{array}$ & $\begin{array}{c}\text { Escherichia } \\
\text { coli }\end{array}$ & & & & & \\
\hline- & - & - & - & - & - & No growth & 1 & \multirow{8}{*}{ ICU } & \multirow{8}{*}{ Hospital bed } & \multirow{8}{*}{1} \\
\hline- & - & - & - & - & - & No growth & 2 & & & \\
\hline- & - & - & - & & $\sqrt{ }$ & 30.000 & 3 & & & \\
\hline- & - & - & - & - & - & No growth & 4 & & & \\
\hline \multirow[t]{2}{*}{-} & - & - & - & - & - & No growth & 5 & & & \\
\hline & & 30.000 & - & & $\sqrt{ }$ & 30.000 & 6 & & & \\
\hline- & - & - & - & - & - & No growth & 7 & & & \\
\hline- & - & - & - & - & - & No growth & 8 & & & \\
\hline- & - & - & - & - & - & No growth & 1 & \multirow{8}{*}{ ICU } & \multirow{8}{*}{ Infusion pump } & \multirow{8}{*}{2} \\
\hline- & - & - & - & - & - & No growth & 2 & & & \\
\hline- & - & - & - & - & - & No growth & 3 & & & \\
\hline- & - & - & - & - & - & No growth & 4 & & & \\
\hline- & - & - & - & - & $\sqrt{ }$ & 30.000 & 5 & & & \\
\hline- & - & - & - & - & - & No growth & 6 & & & \\
\hline- & - & - & - & - & - & No growth & 7 & & & \\
\hline- & - & - & - & - & - & No growth & 8 & & & \\
\hline- & - & - & - & - & - & No growth & 1 & \multirow{8}{*}{ ICU } & \multirow{8}{*}{ Suction device } & \multirow{8}{*}{3} \\
\hline- & - & - & - & - & - & No growth & 2 & & & \\
\hline- & - & - & - & - & - & No growth & 3 & & & \\
\hline- & - & - & - & - & - & No growth & 4 & & & \\
\hline- & - & - & - & - & $\sqrt{ }$ & 30.000 & 5 & & & \\
\hline- & - & - & - & - & - & No growth & 6 & & & \\
\hline- & - & - & - & - & $\sqrt{ }$ & 30.000 & 7 & & & \\
\hline- & - & - & - & - & - & No growth & 8 & & & \\
\hline- & - & - & - & - & - & No growth & 1 & \multirow{8}{*}{ ICU } & \multirow{8}{*}{ Ventilator } & \multirow{8}{*}{4} \\
\hline- & - & - & - & - & - & No growth & 2 & & & \\
\hline- & - & - & - & - & - & No growth & 3 & & & \\
\hline- & - & - & - & - & - & No growth & 4 & & & \\
\hline- & - & - & - & - & - & No growth & 5 & & & \\
\hline- & - & - & - & - & - & No growth & 6 & & & \\
\hline- & - & - & - & - & $\sqrt{ }$ & 50.000 & 7 & & & \\
\hline- & - & - & - & - & - & No growth & 8 & & & \\
\hline
\end{tabular}




\begin{tabular}{|c|c|c|c|c|c|c|c|c|c|c|}
\hline \multicolumn{3}{|c|}{ The growth of the bacteria after UV-C (CFUs) } & \multicolumn{3}{|c|}{ Control Strain(CFUs) } & \multirow{2}{*}{$\begin{array}{c}\text { The growth of } \\
\text { the bacteria } \\
\text { before UV-C } \\
\text { (CFUs) }\end{array}$} & \multirow{2}{*}{$\begin{array}{c}\text { number } \\
\text { of } \\
\text { samples }\end{array}$} & \multirow[b]{2}{*}{ Section } & \multirow[b]{2}{*}{ Equipment } & \multirow[b]{2}{*}{ Row } \\
\hline $\begin{array}{l}\text { Pseudomonas } \\
\text { aeruginosa }\end{array}$ & $\begin{array}{c}\text { Staphylococcus } \\
\text { aureus }\end{array}$ & $\begin{array}{c}\text { Escherichia } \\
\text { coli }\end{array}$ & $\begin{array}{c}\text { Pseudomonas } \\
\text { aeruginosa }\end{array}$ & $\begin{array}{c}\text { Staphylococcus } \\
\text { aureus }\end{array}$ & $\begin{array}{c}\text { Escherichia } \\
\text { coli }\end{array}$ & & & & & \\
\hline \multirow[t]{2}{*}{-} & - & - & - & $\sqrt{ }$ & - & 30.000 & 1 & \multirow{8}{*}{$\mathrm{ICU}$} & \multirow{8}{*}{ Otoscope } & \multirow{8}{*}{5} \\
\hline & - & - & - & - & - & No growth & 2 & & & \\
\hline- & - & - & - & $\sqrt{ }$ & - & 30.000 & 3 & & & \\
\hline- & - & - & - & - & - & No growth & 4 & & & \\
\hline- & - & - & - & $\sqrt{ }$ & - & 50.000 & 5 & & & \\
\hline- & - & - & - & - & - & No growth & 6 & & & \\
\hline- & - & - & - & - & - & No growth & 7 & & & \\
\hline- & - & - & - & - & - & No growth & 8 & & & \\
\hline- & - & - & - & - & - & No growth & 1 & \multirow{8}{*}{$\mathrm{ICU}$} & \multirow{8}{*}{$\begin{array}{l}\text { Blood pressure } \\
\text { meter }\end{array}$} & \multirow{8}{*}{6} \\
\hline- & - & - & - & - & - & No growth & 2 & & & \\
\hline- & - & - & - & - & - & No growth & 3 & & & \\
\hline- & - & - & - & - & $\sqrt{ }$ & 30.000 & 4 & & & \\
\hline- & - & - & - & - & - & No growth & 5 & & & \\
\hline- & - & - & - & - & - & No growth & 6 & & & \\
\hline- & - & - & - & - & - & No growth & 7 & & & \\
\hline- & - & - & - & - & - & No growth & 8 & & & \\
\hline- & - & - & - & - & - & No growth & 1 & \multirow{8}{*}{$\mathrm{ICU}$} & \multirow{8}{*}{ Bed mattress } & \multirow{8}{*}{7} \\
\hline- & - & - & - & - & $\sqrt{ }$ & 50.000 & 2 & & & \\
\hline- & - & - & - & - & - & No growth & 3 & & & \\
\hline- & - & - & - & - & - & No growth & 4 & & & \\
\hline- & - & - & - & - & - & No growth & 5 & & & \\
\hline- & - & - & - & - & - & No growth & 6 & & & \\
\hline- & - & 30.000 & - & - & $\sqrt{ }$ & 30.000 & 7 & & & \\
\hline- & - & - & - & - & - & No growth & 8 & & & \\
\hline- & - & - & - & - & - & No growth & 1 & \multirow{8}{*}{$\mathrm{ICU}$} & \multirow{8}{*}{$\begin{array}{c}\text { Defibrillator } \\
\text { device }\end{array}$} & \\
\hline- & - & - & - & - & - & No growth & 2 & & & \\
\hline- & - & - & - & - & - & No growth & 3 & & & \\
\hline- & - & - & - & - & - & No growth & 4 & & & 8 \\
\hline- & - & - & - & - & - & No growth & 5 & & & 8 \\
\hline- & - & - & - & $\sqrt{ }$ & - & 50.000 & 6 & & & \\
\hline- & - & - & - & - & - & No growth & 7 & & & \\
\hline- & - & - & - & - & - & No growth & 8 & & & \\
\hline- & - & - & - & $\sqrt{ }$ & - & 30.000 & 1 & & & \\
\hline- & - & - & - & - & - & No growth & 2 & & & \\
\hline- & - & - & - & - & - & No growth & 3 & & & \\
\hline- & - & - & - & - & - & No growth & 4 & $\mathrm{ICU}$ & Stethoscone & 9 \\
\hline- & - & - & - & $\sqrt{ }$ & - & 30.000 & 5 & ICU & Stethoscope & 9 \\
\hline- & - & - & - & - & - & No growth & 6 & & & \\
\hline- & - & - & - & - & - & No growth & 7 & & & \\
\hline- & - & - & - & - & - & No growth & 8 & & & \\
\hline- & - & - & - & - & - & No growth & 1 & & & \\
\hline- & - & - & - & - & - & No growth & 2 & & & \\
\hline- & - & - & - & - & - & No growth & 3 & & & \\
\hline- & - & - & - & - & $\sqrt{ }$ & 50.000 & 4 & $\mathrm{OR}$ & Electrosurgery & 10 \\
\hline- & - & - & - & - & - & No growth & 5 & $\mathrm{OK}$ & device & 10 \\
\hline- & - & - & - & - & - & No growth & 6 & & & \\
\hline- & - & - & - & - & - & No growth & 7 & & & \\
\hline- & - & - & - & - & $\sqrt{ }$ & 50.000 & 8 & & & \\
\hline
\end{tabular}




\begin{tabular}{|c|c|c|c|c|c|c|c|c|c|c|}
\hline \multicolumn{3}{|c|}{ The growth of the bacteria after UV-C (CFUs) } & \multicolumn{3}{|c|}{ Control Strain(CFUs) } & \multirow{2}{*}{$\begin{array}{l}\text { The growth of } \\
\text { the bacteria } \\
\text { before UV-C } \\
\text { (CFUs) }\end{array}$} & \multirow{2}{*}{$\begin{array}{c}\text { number } \\
\text { of } \\
\text { samples }\end{array}$} & \multirow[b]{2}{*}{ Section } & \multirow[b]{2}{*}{ Equipment } & \multirow[b]{2}{*}{ Row } \\
\hline $\begin{array}{c}\text { Pseudomonas } \\
\text { aeruginosa }\end{array}$ & $\begin{array}{c}\text { Staphylococcus } \\
\text { aureus }\end{array}$ & $\begin{array}{l}\text { Escherichia } \\
\text { coli }\end{array}$ & $\begin{array}{c}\text { Pseudomonas } \\
\text { aeruginosa }\end{array}$ & $\begin{array}{l}\text { Staphylococcus } \\
\text { aureus }\end{array}$ & $\begin{array}{c}\text { Escherichia } \\
\text { coli }\end{array}$ & & & & & \\
\hline- & - & - & - & - & - & No growth & 1 & \multirow{8}{*}{ OR } & \multirow{8}{*}{ Infusion pump } & \multirow{8}{*}{11} \\
\hline- & - & - & - & $\sqrt{ }$ & - & 30.000 & 2 & & & \\
\hline- & - & - & - & - & - & No growth & 3 & & & \\
\hline- & - & - & - & - & - & No growth & 4 & & & \\
\hline- & - & - & - & $\sqrt{ }$ & - & 30.000 & 5 & & & \\
\hline- & - & - & - & - & - & No growth & 6 & & & \\
\hline- & - & - & 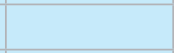 & - & - & No growth & 7 & & & \\
\hline - & - & - & - & - & - & No growth & 8 & & & \\
\hline- & - & - & - & - & - & No growth & 1 & \multirow{8}{*}{ OR } & \multirow{8}{*}{ Stethoscope } & \multirow{8}{*}{12} \\
\hline- & - & - & - & - & - & No growth & 2 & & & \\
\hline- & - & - & - & - & - & No growth & 3 & & & \\
\hline- & - & - & - & - & $\sqrt{ }$ & 50.000 & 4 & & & \\
\hline- & - & - & - & - & - & No growth & 5 & & & \\
\hline- & - & - & - & - & - & No growth & 6 & & & \\
\hline- & - & - & - & - & - & No growth & 7 & & & \\
\hline- & - & - & - & - & - & No growth & 8 & & & \\
\hline- & - & - & - & - & - & No growth & 1 & \multirow{8}{*}{ OR } & \multirow{8}{*}{$\begin{array}{c}\text { Blood pressure } \\
\text { meter }\end{array}$} & \multirow{8}{*}{13} \\
\hline- & - & - & - & - & - & No growth & 2 & & & \\
\hline- & - & - & - & - & - & No growth & 3 & & & \\
\hline- & - & - & - & - & - & No growth & 4 & & & \\
\hline- & - & - & - & - & - & No growth & 5 & & & \\
\hline- & - & - & - & - & - & No growth & 6 & & & \\
\hline- & - & - & - & - & $\sqrt{ }$ & 30.000 & 7 & & & \\
\hline- & - & - & - & - & - & No growth & 8 & & & \\
\hline- & - & - & - & - & - & No growth & 1 & \multirow{8}{*}{ OR } & \multirow{8}{*}{ Surgical Bed } & \multirow{8}{*}{14} \\
\hline- & - & - & - & - & - & No growth & 2 & & & \\
\hline- & - & 30.000 & - & - & $\sqrt{ }$ & 30.000 & 3 & & & \\
\hline- & - & - & $\sqrt{ }$ & - & - & 30.000 & 4 & & & \\
\hline- & - & - & - & - & - & No growth & 5 & & & \\
\hline- & - & - & - & - & - & No growth & 6 & & & \\
\hline- & - & - & - & - & - & No growth & 7 & & & \\
\hline- & - & - & - & - & $\sqrt{ }$ & 30.000 & 8 & & & \\
\hline- & - & - & - & - & - & No growth & 1 & & & 15 \\
\hline- & - & - & - & - & - & No growth & 2 & & & \\
\hline- & - & - & $\sqrt{ }$ & - & - & 30.000 & 3 & & & \\
\hline- & - & - & - & - & - & No growth & 4 & OR & Surgical & \\
\hline- & - & - & - & - & - & No growth & 5 & UK & lighting & \\
\hline- & - & - & - & - & - & No growth & 6 & & & \\
\hline- & - & 30.000 & - & - & $\sqrt{ }$ & 30.000 & 7 & & & \\
\hline- & - & - & - & - & - & No growth & 8 & & & \\
\hline- & - & - & - & - & - & No growth & 1 & & & \\
\hline- & - & - & - & - & - & No growth & 2 & & & \\
\hline- & - & - & - & - & - & No growth & 3 & & & \\
\hline- & - & - & - & - & - & No growth & 4 & OR & Anesthesia & 16 \\
\hline- & - & - & - & - & - & No growth & 5 & & Machine & \\
\hline- & - & - & - & - & $\sqrt{ }$ & 50.0000 & 6 & & & \\
\hline- & - & - & - & - & - & No growth & 7 & & & \\
\hline- & - & - & - & - & - & No growth & 8 & & & \\
\hline
\end{tabular}




\begin{tabular}{|c|c|c|c|c|c|c|c|c|c|c|}
\hline \multicolumn{3}{|c|}{ The growth of the bacteria after UV-C (CFUs) } & \multicolumn{3}{|c|}{ Control Strain(CFUs) } & \multirow{2}{*}{$\begin{array}{l}\text { The growth of } \\
\text { the bacteria } \\
\text { before UV-C } \\
\text { (CFUs) }\end{array}$} & \multirow{2}{*}{$\begin{array}{l}\text { number } \\
\text { of } \\
\text { samples }\end{array}$} & \multirow[b]{2}{*}{ Section } & \multirow[b]{2}{*}{ Equipment } & \multirow[b]{2}{*}{ Row } \\
\hline $\begin{array}{l}\text { Pseudomonas } \\
\text { aeruginosa }\end{array}$ & $\begin{array}{c}\text { Staphylococcus } \\
\text { aureus }\end{array}$ & $\begin{array}{l}\text { Escherichia } \\
\text { coli }\end{array}$ & $\begin{array}{c}\text { Pseudomonas } \\
\text { aeruginosa }\end{array}$ & $\begin{array}{c}\text { Staphylococcus } \\
\text { aureus }\end{array}$ & $\begin{array}{c}\text { Escherichia } \\
\text { coli }\end{array}$ & & & & & \\
\hline- & - & - & - & - & - & No growth & 1 & \multirow{8}{*}{ OR } & \multirow{8}{*}{$\begin{array}{c}\text { Defibrillator } \\
\text { device }\end{array}$} & \multirow{8}{*}{17} \\
\hline- & - & - & - & - & - & No growth & 2 & & & \\
\hline- & - & - & - & - & $\sqrt{ }$ & 30.000 & 3 & & & \\
\hline- & - & - & - & - & - & No growth & 4 & & & \\
\hline- & - & - & - & - & - & No growth & 5 & & & \\
\hline- & - & - & - & - & $\sqrt{ }$ & 50.000 & 6 & & & \\
\hline- & - & - & - & - & - & No growth & 7 & & & \\
\hline- & - & - & - & - & - & No growth & 8 & & & \\
\hline- & - & - & $\sqrt{ }$ & - & - & 30.000 & 1 & \multirow{8}{*}{ ER } & \multirow{8}{*}{ Stethoscope } & \multirow{8}{*}{18} \\
\hline- & - & - & - & - & - & No growth & 2 & & & \\
\hline- & - & - & - & - & - & No growth & 3 & & & \\
\hline- & - & - & - & - & - & No growth & 4 & & & \\
\hline- & - & - & $\sqrt{ }$ & - & - & 30.000 & 5 & & & \\
\hline- & - & - & - & - & - & No growth & 6 & & & \\
\hline- & - & - & - & - & - & No growth & 7 & & & \\
\hline- & - & - & - & - & - & No growth & 8 & & & \\
\hline- & - & - & - & $\sqrt{ }$ & - & 50.000 & 1 & \multirow{8}{*}{ ER } & \multirow{8}{*}{ Otoscope } & \multirow{8}{*}{19} \\
\hline- & - & - & - & - & - & No growth & 2 & & & \\
\hline- & - & - & - & - & - & No growth & 3 & & & \\
\hline- & - & - & - & $\sqrt{ }$ & - & 50.000 & 4 & & & \\
\hline- & - & - & $\sqrt{ }$ & - & - & 30.000 & 5 & & & \\
\hline- & - & - & - & - & - & No growth & 6 & & & \\
\hline- & - & - & - & - & - & No growth & 7 & & & \\
\hline- & - & - & $\sqrt{ }$ & - & - & 50.000 & 8 & & & \\
\hline- & - & - & - & - & - & No growth & 1 & \multirow{8}{*}{ ER } & \multirow{8}{*}{$\begin{array}{c}\text { Blood pressure } \\
\text { meter }\end{array}$} & \multirow{8}{*}{20} \\
\hline- & - & - & - & - & - & No growth & 2 & & & \\
\hline- & - & - & - & - & - & No growth & 3 & & & \\
\hline- & - & - & - & - & - & No growth & 4 & & & \\
\hline- & - & - & - & - & - & No growth & 5 & & & \\
\hline- & - & - & - & - & $\sqrt{ }$ & 30.000 & 6 & & & \\
\hline- & - & - & - & - & - & No growth & 7 & & & \\
\hline- & - & - & - & - & - & No growth & 8 & & & \\
\hline
\end{tabular}

\section{REFERENCES}

${ }^{[1]}$ Dunn PM. Oliver Wendell Holmes (1809-1894) and his essay on puerperal fever. Arch Dis Child Fetal Neonatal Ed. 2007; 92:F325-7.

${ }^{[2]}$ Hughes R, ed. Patient safety and quality: An evidence-based handbook for nurses. Rockville, MD: Agency for Healthcare Research and Quality; 2008.

${ }^{[3]}$ Gholampour S, Fatouraee N, Seddighi AS, Yazdani SO. A Hydrodynamical Study to propose a numerical Index for evaluating the CSF conditions in cerebralventricular system. Int Clin Neurosci J 2014;1:1-9.

${ }^{[4]}$ Gholampour S, Fatouraee N, Seddighi AS, Seddighi A. Numerical simulation of cerebrospinal fluid hydrodynamics in the healing process of hydrocephalus patients. J Appl Mech Tech Phy 2017;58:386-91.
${ }^{[5]}$ Gholampour S, Fatouraee N, Seddighi AS, Seddighi A. Evaluating the effect of hydrocephalus cause on the manner of changes in the effective parameters and clinical symptoms of the disease. J Clin Neurosci 2017;35:50-5.

${ }^{[6]}$ Gholampour S. FSI simulation of CSF hydrodynamic changes in a large population of non-communicating hydrocephalus patients during treatment process with regard to their clinical symptoms. PloS One. 2018;13:e0196216.

${ }^{[7]}$ Gholampour S, Soleimani N, Zalii AR, Seddighi A. Numerical simulation of the cervical spine in a normal subject and a patient with intervertebral cage under various loadings and in various positions. Int Clin Neurosci J 2016;3(2):92-8.

${ }^{[8]}$ Gholampour S, Taher M. Relationship of morphologic changes in the brain and spinal cord and disease symptoms with cerebrospinal fluid hydrodynamic changes in patients with Chiari malformation type I. World Neurosurg 2018;116:e830-9. 
${ }^{[9]}$ Gholampour S, Bahmani M, Shariati A. Comparing the efficiency of two treatment methods of hydrocephalus: shunt implantation and endoscopic third ventriculostomy. Basic Clin Neurosci 2019;10:185-98.

${ }^{[10]}$ Gholampour S, Shakouri E, Deh HH. Effect of drilling direction and depth on thermal necrosis during tibia drilling: an in vitro study. Technol Health Care 2018;26:687-97.

${ }^{[11]}$ Gholampour S, Jalali A. Thermal analysis of the dentine tubule under hot and cold stimuli using fluid-structure interaction simulation. Biomech Model Mechanobiol 2018;17:1599-610.

${ }^{[12]}$ Hajirayat K, Gholampour S, Sharifi I, Bizari D. Biomechanical Simulation to Compare the Blood Hemodynamics and Cerebral Aneurysm Rupture Risk in Patients with Different Aneurysm Necks. J Appl Mech Tech Phy 2017;58:968-74.

${ }^{[13]}$ Hajirayat K, Gholampour S, Seddighi AS, Fatouraee N. Evaluation of Blood Hemodynamics in Patients with Cerebral Aneurysm. Int Clin Neurosci J 2016;3:44-50.

${ }^{[14]}$ Jamalabadi MY, Daqiqshirazi M, Nasiri H, Safaei MR, Nguyen TK. Modeling and analysis of biomagnetic blood Carreau fluid flow through a stenosis artery with magnetic heat transfer: A transient study. PloS One. 2018;13:e0192138.

${ }^{[15]}$ Amiri MH, Keshavarzi A, Karimipour A, Bahiraei M, Goodarzi M, Esfahani JA. A 3-D numerical simulation of non-Newtonian blood flow through femoral artery bifurcation with a moderate arteriosclerosis: investigating Newtonian/non-Newtonian flow and its effects on elastic vessel walls. Heat Mass Transfer 2019;55:2037-47.

${ }^{[16]}$ Chinn RY, Sehulster L. Guidelines for environmental infection control in health-care facilities; recommendations of CDC and Healthcare Infection Control Practices Advisory Committee (HICPAC). MMWR Recomm Rep 2003;52(RR-10):1-42.

${ }^{[17]}$ Doll M, Stevens M, Bearman G. Environmental cleaning and disinfection of patient areas. Int J Infect Dis 2018;67:52-7.

${ }^{[18]}$ Kovach CR, Taneli Y, Neiman T, Dyer EM, Arzaga AJ, Kelber ST. Evaluation of an ultraviolet room disinfection protocol to decrease nursing home microbial burden, infection and hospitalization rates. BMC Infect Dis 2017;17:186.

${ }^{[19]}$ Gostine A, Gostine D, Donohue C, Carlstrom L. Evaluating the effectiveness of ultraviolet-C lamps for reducing keyboard contamination in the intensive care unit: A longitudinal analysis. Am J Infect Control 2016;44:1089-94.

${ }^{[20]}$ Ghannoum MA, Isham N, Long L. Optimization of an infected shoe model for the evaluation of an ultraviolet shoe sanitizer device. J Am Podiatr Med Assoc 2012;102:309-13.
${ }^{[21]}$ Timmermann LF, Ritter K, Hillebrandt D, Küpper T. Drinking water treatment with ultraviolet light for travelers-Evaluation of a mobile lightweight system. Travel Med Infect Dis 2015;13:466-74.

${ }^{[22]}$ Messina G, Burgassi S, Messina D, Montagnani V, Cevenini G. A new UV-LED device for automatic disinfection of stethoscope membranes. Am J Infect Control 2015;43:e61-6.

${ }^{[23]}$ Rutala WA, Gergen MF, Weber DJ. Room decontamination with UV radiation. Infect Control Hosp Epidemiol 2010; 31:1025-9.

${ }^{[24]}$ Boyce JM. Modern technologies for improving cleaning and disinfection of environmental surfaces in hospitals. Antimicrob Resist Infect Control 2016;5:10.

${ }^{[25]}$ Knelson LP, Williams DA, Gergen MF, et al. A comparison of environmental contamination by patients infected or colonized with methicillin-resistant Staphylococcus aureus or vancomycin-resistant enterococci: a multicentre study. Infect Control Hosp Epidemiol 2014;35:872-5.

${ }^{[26]}$ Lin D, Ou Q, Lin J, Peng Y, Yao Z. A meta-analysis of the rates of Staphylococcus aureus and methicillin-resistant $S$ aureus contamination on the surfaces of environmental objects that health care workers frequently touch. Am J Infect Control 2017;45:421-9.

${ }^{[27]}$ Döring G, Jansen S, Noll H, et al. Distribution and transmission of Pseudomonas aeruginosa and Burkholderia cepacia in a hospital ward. Pediatr Pulmonol 1996;21:90-100.

${ }^{[28]}$ Kramer A, Schwebke I, Kampf G. How long do nosocomial pathogens persist on inanimate surfaces? A systematic review. BMC Infect Dis 2006;6:130.

${ }^{[29]}$ Health Quality Ontario. Continuous monitoring of glucose for type 1 diabetes: a health technology assessment. Ont Health Technol Assess Ser 2018;18:1-160.

${ }^{[30]}$ Lall R, Sahu A, Jaiswal A, Kite S, Sowmya AR, Sainath MC. Evaluation of Various Sterilization Processes of Orthodontic Instruments using Biological Indicators and Conventional Swab Test Method: A Comparative Study. J Contemp Dent Pract 2018;19:698-703.

${ }^{[31]}$ National Committee for Clinical Laboratory Standards (US). Methods for dilution antimicrobial susceptibility tests for bacteria that grow aerobically: approved standard. National Committee for Clinical Laboratory Standards; 2006.

${ }^{[32]}$ Melvin P. W. Performance Standards for Antimicrobial Disk Susceptibility Tests; Approved Standard $-11^{\text {th }}$ ed. CLSI document M02-A11, 2012. 